\title{
Dimericchalasine A and Amichalasines D and E: Unexpected Cytochalasan Homodimer and Heterotrimers from Aspergillus micronesiensis PG-1
}

Zhaodi Wu ${ }^{\dagger}$ Xiaotian Zhang, ${ }^{\dagger}$ Chunmei Chen,${ }^{\dagger}$ Peng Zhou, Mi Zhang, Lianghu Gu, Zengwei Luo, Jianping Wang, Qingyi Tong, * Hucheng Zhu,* and Yonghui Zhang*

Hubei Key Laboratory of Natural Medicinal Chemistry and Resource Evaluation, School of Pharmacy, Tongji Medical College, Huazhong University of Science and Technology, Wuhan 430030, China 


\section{CONTENTS}

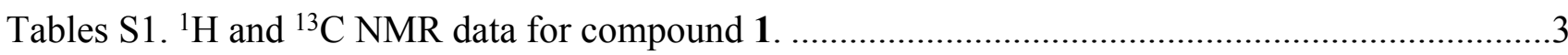

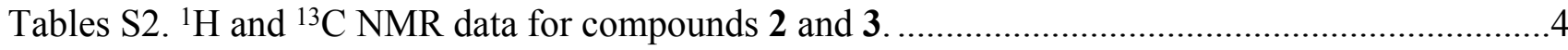

Figure S1. Key ${ }^{1} \mathrm{H}^{-1} \mathrm{H}$ COSY and HMBC correlations and fusion pattern of units $\mathrm{A}-\mathrm{C}$ of $2 \ldots \ldots \ldots \ldots . . .5$

Figure S2. Core structure of the two possible candidates of $\mathbf{2}$ (2a and $\mathbf{2 b}$ ), distances between key

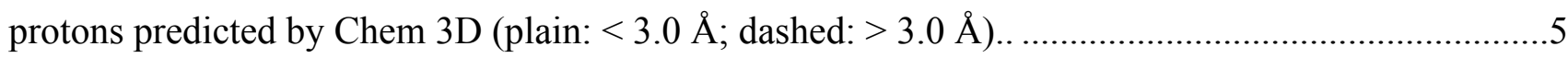

Figure S3. Key ${ }^{1} \mathrm{H}^{-1} \mathrm{H}$ COSY and HMBC correlations and fusion pattern of units $\mathrm{A}-\mathrm{C}$ of $3 \ldots \ldots \ldots \ldots . .5$

Figure S4. Key ROESY correlations of unit A in compound 3..............................................6

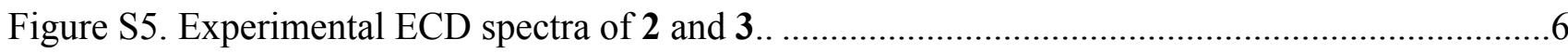

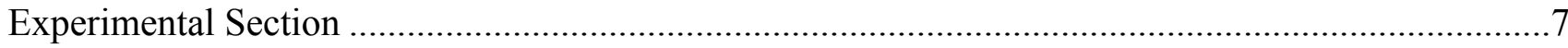

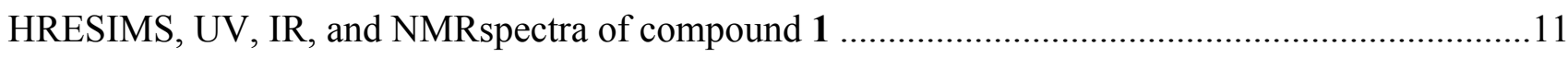

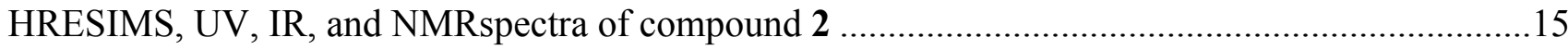

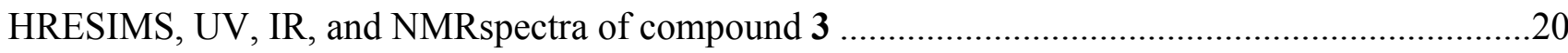


Table S1. ${ }^{1} \mathrm{H}$ and ${ }^{13} \mathrm{C}$ NMR data for compound $1 .^{\mathrm{a}}$

\begin{tabular}{|c|c|c|c|c|c|}
\hline \multirow[b]{2}{*}{ no. } & \multicolumn{5}{|c|}{1} \\
\hline & $\delta_{\mathrm{H}}$ & $\delta_{\mathrm{C}}$ & no. & $\delta_{\mathrm{H}}$ & $\delta_{\mathrm{C}}$ \\
\hline 1 & & 176.4 & $1^{\prime}$ & & 175.1 \\
\hline 3 & 3.02 ddd $(11.2,4.5,2.4)$ & 52.9 & $3^{\prime}$ & $2.98 \mathrm{~m}$ & 51.3 \\
\hline 4 & $2.17 \mathrm{t}(4.5)$ & 55.6 & $4^{\prime}$ & $2.10 \mathrm{t}(4.5)$ & 55.8 \\
\hline 5 & $2.61 \mathrm{~m}$ & 36.2 & $5^{\prime}$ & $2.50 \mathrm{~m}$ & 35.7 \\
\hline 6 & & 140.3 & $6^{\prime}$ & & 139.4 \\
\hline 7 & 5.34 brs & 126.0 & $7^{\prime}$ & $5.31 \mathrm{brs}$ & 126.2 \\
\hline 8 & 3.22 brd (11.3) & 44.0 & $8^{\prime}$ & 3.22 brd (11.0) & 42.7 \\
\hline 9 & & 68.2 & $9^{\prime}$ & & 68.5 \\
\hline $10 \mathrm{a}$ & $2.37 \mathrm{~m}$ & 46.5 & $10^{\prime} \mathrm{a}$ & $1.81 \mathrm{~m}$ & 47.5 \\
\hline $10 \mathrm{~b}$ & $1.14 \mathrm{~m}$ & & $10^{\prime} \mathrm{b}$ & $1.29 \mathrm{~m}$ & \\
\hline 11 & $1.18 \mathrm{~d}(7.0)$ & 14.6 & $11^{\prime}$ & $1.17 \mathrm{~d}(7.0)$ & 14.1 \\
\hline 12 & $1.76 \mathrm{~s}$ & 20.5 & $12^{\prime}$ & $1.74 \mathrm{~s}$ & 20.2 \\
\hline 13 & $5.87 \mathrm{~d}(11.3)$ & 124.2 & $13^{\prime}$ & $6.10 \mathrm{~d}(11.0)$ & 124.7 \\
\hline 14 & & 138.3 & $14^{\prime}$ & & 137.4 \\
\hline $15 \mathrm{a}$ & $2.04 \mathrm{~m}$ & 39.3 & $15^{\prime} \mathrm{a}$ & $2.13 \mathrm{~m}$ & 30.8 \\
\hline $15 b$ & $2.04 \mathrm{~m}$ & & $15^{\prime} \mathrm{b}$ & $1.96 \mathrm{~m}$ & \\
\hline $16 \mathrm{a}$ & $1.83 \mathrm{~m}$ & 20.6 & $16^{\prime} \mathrm{a}$ & $2.22 \mathrm{~m}$ & 33.1 \\
\hline $16 b$ & $1.58 \mathrm{~m}$ & & $16^{\prime} \mathrm{b}$ & $2.08 \mathrm{~m}$ & \\
\hline $17 \mathrm{a}$ & $1.86 \mathrm{~m}$ & 32.1 & $17^{\prime}$ & 4.05 brs & 74.5 \\
\hline $17 b$ & $1.75 \mathrm{~m}$ & & & & \\
\hline 18 & $5.33 \mathrm{~m}$ & 73.3 & $18^{\prime}$ & & 210.0 \\
\hline 19 & & 200.8 & $19^{\prime} \mathrm{a}$ & $4.48 \mathrm{dd}(20.8,4.0)$ & 35.1 \\
\hline & & & $19^{\prime} \mathrm{b}$ & $2.38 \mathrm{~m}$ & \\
\hline 20 & $6.24 \mathrm{~d}(10.9)$ & 58.7 & $20^{\prime}$ & $3.82 \mathrm{dt}(10.9,4.0)$ & 54.0 \\
\hline 21 & & 208.6 & $21^{\prime}$ & & 210.9 \\
\hline 22 & $1.72 \mathrm{~m}$ & 25.7 & $22^{\prime}$ & $1.64 \mathrm{~m}$ & 25.3 \\
\hline 23 & $0.95 \mathrm{~d}(6.5)$ & 24.3 & $23^{\prime}$ & $0.99 \mathrm{~d}(6.5)$ & 23.7 \\
\hline 24 & $0.96 \mathrm{~d}(6.5)$ & 21.3 & $24^{\prime}$ & $0.96 \mathrm{~d}(6.5)$ & 21.5 \\
\hline 25 & $1.25 \mathrm{~s}$ & 15.1 & $25^{\prime}$ & $1.30 \mathrm{~s}$ & 18.5 \\
\hline
\end{tabular}

a $600 \mathrm{MHz}$ for ${ }^{1} \mathrm{H}$ and $150 \mathrm{MHz}$ for ${ }^{13} \mathrm{C}$, measured in $\mathrm{CDCl}_{3}$. 
Table S2. ${ }^{1} \mathrm{H}$ and ${ }^{13} \mathrm{C}$ NMR data for compounds 2 and 3.

\begin{tabular}{|c|c|c|c|c|c|c|c|c|c|c|c|}
\hline \multirow[t]{2}{*}{ no. } & \multicolumn{5}{|c|}{2} & \multirow[b]{2}{*}{ no. } & \multicolumn{5}{|c|}{3} \\
\hline & $\delta_{\mathrm{H}}(J$ in $\mathrm{Hz})$ & $\delta_{\mathrm{C}}$ & no. & $\delta_{\mathrm{H}}(J$ in $\mathrm{Hz})$ & $\delta_{\mathrm{C}}$ & & $\delta_{\mathrm{H}}(J$ in $\mathrm{Hz})$ & $\delta_{\mathrm{C}}$ & no. & $\delta_{\mathrm{H}}(J$ in $\mathrm{Hz})$ & $\delta_{\mathrm{C}}$ \\
\hline 1 & & 177.3 & $1^{\prime}$ & & 172.9 & 1 & & 177.1 & $1^{\prime}$ & & 173.4 \\
\hline 3 & 3.20 ddd $(8.3,6.1,2.5)$ & 52.7 & $3^{\prime}$ & $2.95 \mathrm{~m}$ & 54.4 & 3 & $\begin{array}{l}3.42 \text { ddd }(10.8,3.8, \\
1.6)\end{array}$ & 52.4 & $3^{\prime}$ & $2.98 \mathrm{ddd}(11.3,4.9,2.0)$ & 54.6 \\
\hline 4 & $2.94 \mathrm{~m}$ & 52.2 & $4^{\prime}$ & $2.50 \mathrm{~m}$ & 53.7 & 4 & $2.40 \mathrm{dd}(6.4,1.6)$ & 52.1 & $4^{\prime}$ & $2.58 \mathrm{t}(4.5)$ & 53.7 \\
\hline 5 & $2.48 \mathrm{~m}$ & 37.2 & $5^{\prime}$ & $2.65 \mathrm{~m}$ & 36.0 & 5 & $2.83 \mathrm{~m}$ & 36.5 & $5^{\prime}$ & $2.70 \mathrm{~m}$ & 35.8 \\
\hline 6 & & 141.8 & $6^{\prime}$ & & 142.9 & 6 & & 140.6 & $6^{\prime}$ & & 142.9 \\
\hline 7 & $5.30 \mathrm{brs}$ & 126.0 & $7^{\prime}$ & $5.21 \mathrm{brs}$ & 123.6 & 7 & $5.38 \mathrm{brs}$ & 127.3 & $7^{\prime}$ & 5.27 brs & 123.5 \\
\hline 8 & $3.99 \mathrm{~m}$ & 47.1 & $8^{\prime}$ & 3.10 brd (11.0) & 43.2 & 8 & 3.10 brs & 40.1 & $8^{\prime}$ & 3.16 brd (11.2) & 43.0 \\
\hline 9 & & 69.2 & $9^{\prime}$ & & 88.9 & 9 & & 69.6 & $9^{\prime}$ & & 89.6 \\
\hline $10 \mathrm{a}$ & $1.62 \mathrm{~m}$ & 48.8 & $10^{\prime} \mathrm{a}$ & $1.90 \mathrm{~m}$ & 48.0 & $10 \mathrm{a}$ & $1.30 \mathrm{~m}$ & 49.0 & $10^{\prime} \mathrm{a}$ & $1.87 \mathrm{~m}$ & 48.7 \\
\hline $10 \mathrm{~b}$ & $1.39 \mathrm{~m}$ & & $10^{\prime} \mathrm{b}$ & $1.23 \mathrm{~m}$ & & $10 \mathrm{~b}$ & $1.12 \mathrm{~m}$ & & $10^{\prime} \mathrm{b}$ & $1.27 \mathrm{~m}$ & \\
\hline 11 & $1.26 \mathrm{~d}(7.2)$ & 14.0 & $11^{\prime}$ & $1.22 \mathrm{~d}(7.2)$ & 15.0 & 11 & $1.29 \mathrm{~d}(7.1)$ & 13.9 & $11^{\prime}$ & $1.22 \mathrm{~d}(7.3)$ & 15.2 \\
\hline 12 & $1.77 \mathrm{~s}$ & 20.0 & $12^{\prime}$ & $1.77 \mathrm{~s}$ & 20.3 & 12 & $1.77 \mathrm{~s}$ & 19.7 & $12^{\prime}$ & $1.79 \mathrm{~s}$ & 20.3 \\
\hline 13 & $5.95 \mathrm{~d}(10.7)$ & 125.6 & $13^{\prime}$ & $5.53 \mathrm{~d}(11.0)$ & 126.1 & 13 & 5.90 brd (7.0) & 124.3 & $13^{\prime}$ & $5.48 \mathrm{~d}(11.2)$ & 126.4 \\
\hline 14 & & 138.5 & $14^{\prime}$ & & 138.9 & 14 & & 143.8 & $14^{\prime}$ & & 139.0 \\
\hline $15 \mathrm{a}$ & $2.06 \mathrm{~m}$ & 35.0 & $15^{\prime} \mathrm{a}$ & $2.14 \mathrm{~m}$ & 33.5 & $15 \mathrm{a}$ & $2.11 \mathrm{~m}$ & 33.3 & $15^{\prime} \mathrm{a}$ & $2.18 \mathrm{~m}$ & 33.2 \\
\hline $15 b$ & $1.97 \mathrm{~m}$ & & $15^{\prime} \mathrm{b}$ & $2.07 \mathrm{~m}$ & & $15 b$ & $2.00 \mathrm{~m}$ & & $15^{\prime} \mathrm{b}$ & $2.07 \mathrm{~m}$ & \\
\hline $16 \mathrm{a}$ & $2.02 \mathrm{~m}$ & 32.3 & $16^{\prime} \mathrm{a}$ & $2.30 \mathrm{~m}$ & 34.0 & $16 \mathrm{a}$ & $2.16 \mathrm{~m}$ & 33.0 & $16^{\prime} \mathrm{a}$ & $2.30 \mathrm{~m}$ & 34.2 \\
\hline $16 b$ & $1.72 \mathrm{~m}$ & & $16^{\prime} \mathrm{b}$ & $2.07 \mathrm{~m}$ & & $16 b$ & $1.87 \mathrm{~m}$ & & $16^{\prime} \mathrm{b}$ & $2.15 \mathrm{~m}$ & \\
\hline 17 & $4.30 \mathrm{dd}(8.0,7.4)$ & 77.3 & $17^{\prime}$ & $4.45 \mathrm{dd}(8.0,7.6)$ & 76.3 & 17 & $4.24 \mathrm{dd}(7.5,1.5)$ & 77.8 & $17^{\prime}$ & $4.51 \mathrm{dd}(7.6,1.7)$ & 76.3 \\
\hline 18 & & 209.2 & $18^{\prime}$ & & 205.4 & 18 & & 204.7 & $18^{\prime}$ & & 206.1 \\
\hline 19 & $3.13 \mathrm{~d}(5.2)$ & 55.4 & $19^{\prime}$ & $3.89 \mathrm{~d}(5.3)$ & 52.7 & 19 & $3.74 \mathrm{dd}(6.4,4.9)$ & 59.5 & $19^{\prime}$ & $4.23 \mathrm{~d}(5.0)$ & 53.2 \\
\hline 20 & $5.26 \mathrm{t}(5.2)$ & 51.7 & $20^{\prime}$ & $3.47 \mathrm{~d}(5.3)$ & 43.8 & 20 & $4.04 \mathrm{~d}(6.4)$ & 48.8 & $20^{\prime}$ & $3.55 \mathrm{~d}(5.0)$ & 44.3 \\
\hline 21 & & 210.0 & $21^{\prime}$ & & 171.4 & 21 & & 212.9 & $21^{\prime}$ & & 173.2 \\
\hline 22 & $1.70 \mathrm{~m}$ & 25.9 & $22^{\prime}$ & $1.74 \mathrm{~m}$ & 26.1 & 22 & $1.68 \mathrm{~m}$ & 25.8 & $22^{\prime}$ & $1.77 \mathrm{~m}$ & 26.6 \\
\hline 23 & $0.95 \mathrm{~d}(6.5)$ & 24.1 & $23^{\prime}$ & $0.99 \mathrm{~d}(6.6)$ & 24.8 & 23 & $0.94 \mathrm{~d}(6.5)$ & 24.5 & $23^{\prime}$ & 0.99 d (6.6) & 25.5 \\
\hline 24 & $0.90 \mathrm{~d}(6.5)$ & 22.5 & $24^{\prime}$ & $0.94 \mathrm{~d}(6.6)$ & 21.1 & 24 & $0.93 \mathrm{~d}(6.5)$ & 21.6 & $24^{\prime}$ & $0.95 \mathrm{~d}(6.6)$ & 21.3 \\
\hline 25 & $1.35 \mathrm{~s}$ & 15.7 & $25^{\prime}$ & $1.42 \mathrm{~s}$ & 17.8 & 25 & $1.32 \mathrm{~s}$ & 18.4 & $25^{\prime}$ & $1.44 \mathrm{~s}$ & 18.0 \\
\hline $1^{\prime \prime}$ & $5.35 \mathrm{~d}(5.2)$ & 82.2 & $6^{\prime \prime}$ & & 127.3 & $1^{\prime \prime}$ & $4.97 \mathrm{~d}(0.9)$ & 84.8 & $6^{\prime \prime}$ & & 132.6 \\
\hline $2^{\prime \prime}$ & & 64.0 & $7 "$ & & 161.8 & $2^{\prime \prime}$ & & 65.3 & $7^{\prime \prime}$ & & 157.9 \\
\hline $3^{\prime \prime}$ & & 196.6 & $8^{\prime \prime}$ & $5.60 \mathrm{~s}$ & 83.7 & $3^{\prime \prime}$ & & 198.2 & $8^{\prime \prime}$ & $5.77 \mathrm{~d}(4.9)$ & 82.0 \\
\hline $4^{\prime \prime}$ & & 91.1 & $9^{\prime \prime}$ & $1.89 \mathrm{~s}$ & 11.8 & $4^{\prime \prime}$ & & 91.8 & $9^{\prime \prime}$ & $1.53 \mathrm{~s}$ & 12.6 \\
\hline $5^{\prime \prime}$ & & 196.1 & & & & $5^{\prime \prime}$ & & 195.5 & & & \\
\hline
\end{tabular}

${ }^{a} 800 \mathrm{MHz}$ for ${ }^{1} \mathrm{H}$ and $200 \mathrm{MHz}$ for ${ }^{13} \mathrm{C}$, measured in $\mathrm{CD}_{3} \mathrm{OD}$. 

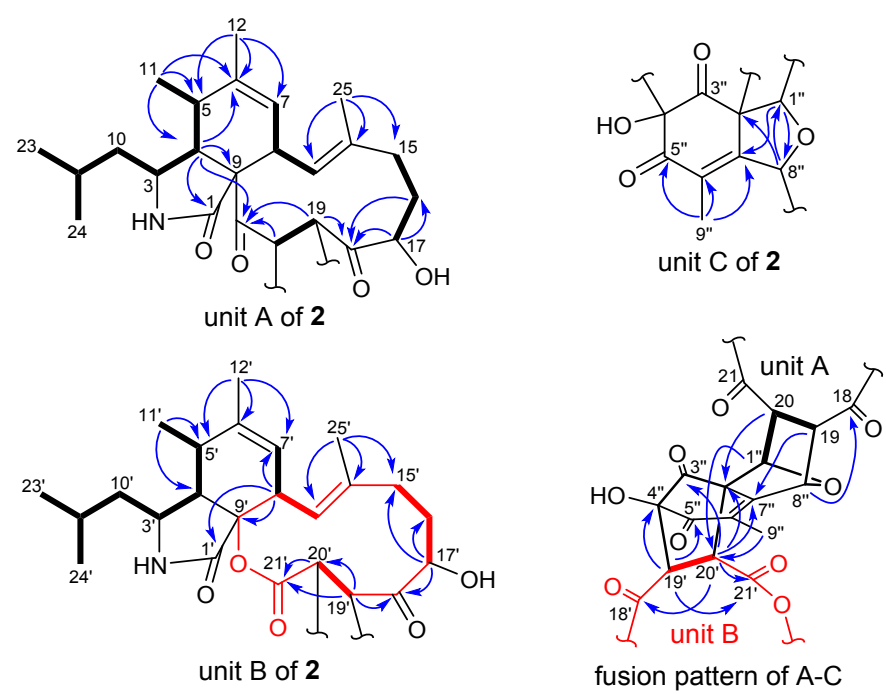

Figure S1. Key ${ }^{1} \mathrm{H}^{-1} \mathrm{H}$ COSY and $\mathrm{HMBC}$ correlations and fusion pattern of units $\mathrm{A}-\mathrm{C}$ of $\mathbf{2}$.
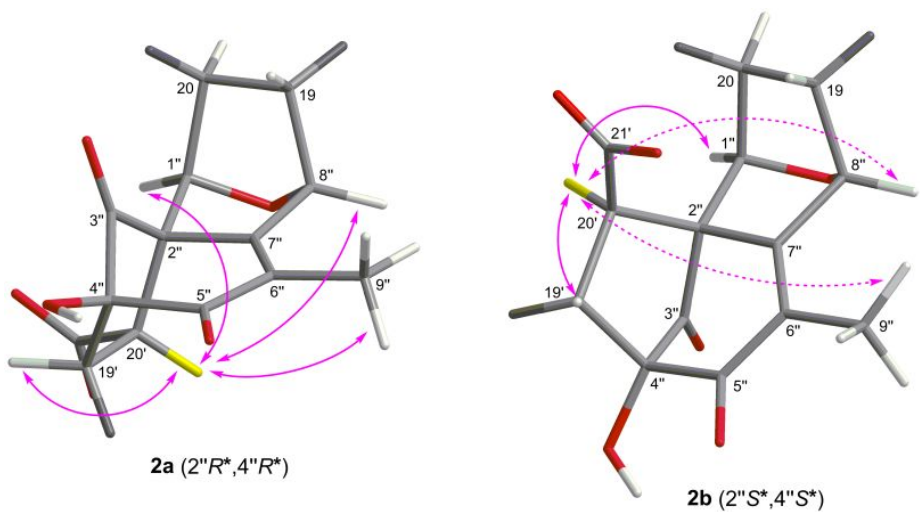

Figure S2. Core structure of the two possible candidates of 2 ( $2 a$ and $2 b)$, distances between key protons predicted by Chem 3D (plain: <3.0 Aं; dashed: > $3.0 \AA$ ).

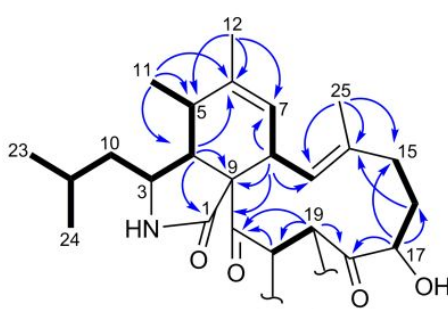

unit $\mathrm{A}$ of 3

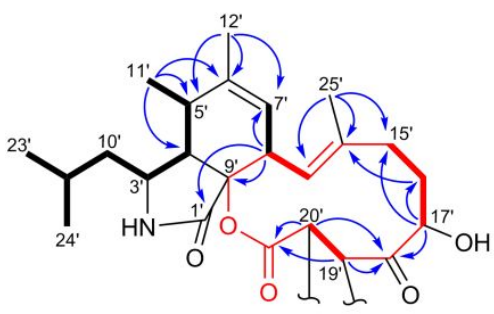

unit B of 3
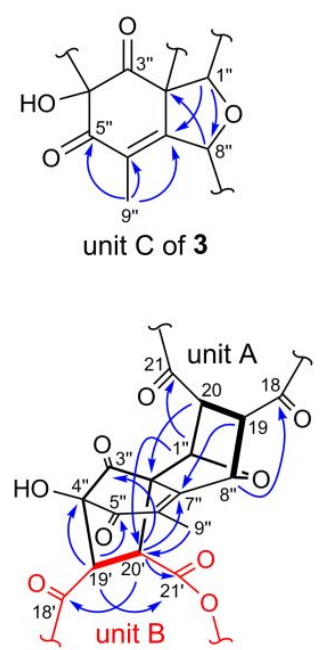

fusion pattern of $\mathrm{A}-\mathrm{C}$

Figure S3. Key ${ }^{1} \mathrm{H}^{-1} \mathrm{H}$ COSY and $\mathrm{HMBC}$ correlations and fusion pattern of units $\mathrm{A}-\mathrm{C}$ of $\mathbf{3}$. 


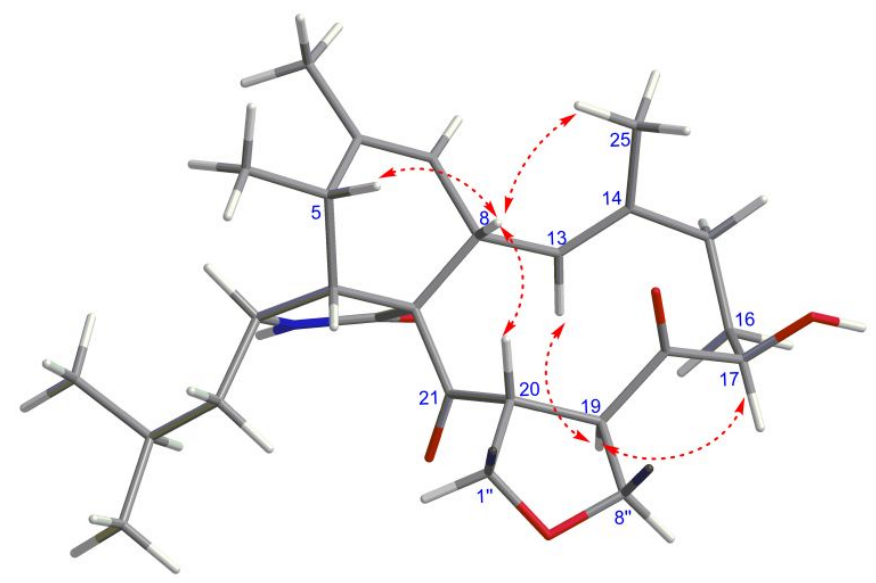

Figure S4. Key ROESY correlations of unit A in compound 3.

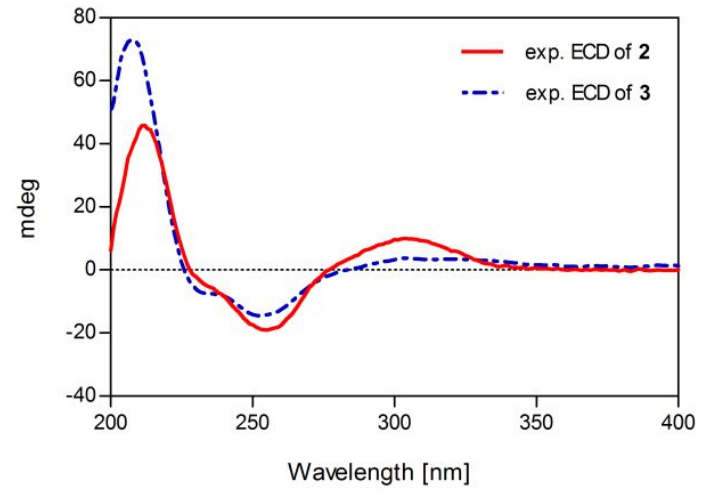

Figure S5. Experimental ECD spectra of $\mathbf{2}$ and $\mathbf{3}$. 


\section{Experimental section}

\section{General experimental procedures.}

UV, IR, and ECD spectra and optical rotations were measured on a Shimadzu UV1750 spectrometer, a Bruker Vertex 70 FT-IR instrument, a JASCO-810 spectrometer, and a Perkin-Elmer 341 polarimeter, respectively. High-resolution electrospray ionization mass spectroscopy (HRESIMS) was obtained using a Thermo Fisher LC-LTQ-Orbitrap XL spectrometer with a TOF analyzer. NMR spectra were recorded using Bruker AM-600 and AM-800 spectrometers. The ${ }^{1} \mathrm{H}$ and ${ }^{13} \mathrm{C}$ NMR chemical shifts were referenced to the solvent or solvent impurity peaks (for $\mathrm{CDCl}_{3}$ at $\delta_{\mathrm{H}} 7.26$ and $\delta_{\mathrm{C}} 77.16 \mathrm{ppm}$; for $\mathrm{CD}_{3} \mathrm{OD}$ at $\delta_{\mathrm{H}} 3.31$ and $\left.\delta_{\mathrm{C}} 49.0 \mathrm{ppm}\right)$. Semipreparative high-performance liquid chromatography (HPLC) was performed using a Dionex Ultimate 3000 HPLC (Dionex, Sunnyvale, CA, USA) with a UV detector and a Welch Ultimate XB-C $18(10 \times 250 \mathrm{~mm}, 5 \mu \mathrm{m})$ column. Silica gel $(100-200 \mathrm{mesh}$ and 200-300 mesh, Qingdao Marine Chemical Inc., Qingdao, China), ODS (50 $\mu \mathrm{m}$, YMC, Japan), and Sephadex LH-20 (Pharmacia Biotech AB, Uppsala, Sweden) were used for column chromatography (CC). Thin-layer chromatography (TLC) was performed with RP-C ${ }_{18} \mathrm{~F}_{254}$ plates (Merck, Germany) and silica gel $60 \mathrm{~F}_{254}$ (Yantai Chemical Industry Research Institute).

\section{Fungal material.}

The strain used in this work was isolated from the root of the traditional Chinese medicinal plant Phyllanthus glaucus, which was collected from LuShan Mountain, Jiangxi Province, China (2015). Its sequence data have been submitted to the DDBJ/EMBL/GenBank database with the accession No. MH938722. A voucher sample (ZYH20150717) has been preserved in the culture collection center of Tongji Medical College, Huazhong University of Science and Technology.

\section{Fermentation and isolation.}

The strain was cultured on potato dextrose agar (PDA) for 5 days to prepare the seed culture. Agar plugs were inoculated into Erlenmeyer flasks (1 L), each containing $200 \mathrm{~g}$ of rice and $200 \mathrm{ml}$ of water, and each flask had been previously sterilized by autoclaving. All flasks were incubated at $25^{\circ} \mathrm{C}$ for five weeks. The fermented rice substrate was extracted seven times with 95\% aqueous EtOH at room temperature, and the solvent was evaporated under vacuum. The residue was then partitioned with EtOAc to afford the EtOAc fraction (approximately $120 \mathrm{~g}$ ). The EtOAc extract was subjected to silica gel CC firstly eluting with petroleum ether-EtOAc $(20: 1-5: 1)$ to remove the majority of the lipids and 
steroids on silica gel $\mathrm{CC}$, and then eluting with $\mathrm{CH}_{2} \mathrm{Cl}_{2}-\mathrm{MeOH}(100: 1-0: 1)$ to furnish eight fractions (Fr. A-H).

Fraction B (10.0 g) was separated on ODS CC (gradient elution with $\left.\mathrm{MeOH}-\mathrm{H}_{2} \mathrm{O}, 50: 50-100: 0\right)$ to afford eight subfractions (Fr. B1-B8). Fr. B7 (eluted with $\mathrm{MeOH}-\mathrm{H}_{2} \mathrm{O}, 90: 10$ ) was chromatographed on Sephadex LH-20 $\left(\mathrm{CH}_{2} \mathrm{Cl}_{2}-\mathrm{MeOH}, 1: 1\right)$ and silica gel $\mathrm{CC}$ and then purified by semipreparative HPLC $\left(\mathrm{MeCN}-\mathrm{H}_{2} \mathrm{O}, 92: 8, \mathrm{v}=2.0 \mathrm{ml} / \mathrm{min}\right)$ to afford compound $1\left(16.7 \mathrm{mg}, t_{\mathrm{R}}=46.6 \mathrm{~min}\right)$.

Fraction E (18.0 g) was separated on ODS CC (gradient elution with $\left.\mathrm{MeOH}-\mathrm{H}_{2} \mathrm{O}, 40: 60-100: 0\right)$ to afford seven subfractions (Fr. E1-E7). Fr. E5 (eluted with $\mathrm{MeOH}-\mathrm{H}_{2} \mathrm{O}, 90: 10$ ) was chromatographed on Sephadex LH-20 (MeOH- $\left.\mathrm{CH}_{2} \mathrm{Cl}_{2}, 1: 1\right)$ followed by silica gel to give three subfractions (Fr. E5.1E5.3). Fr. E5.1 was purified by semipreparative HPLC $\left(\mathrm{MeCN}-\mathrm{H}_{2} \mathrm{O}, 85: 15, \mathrm{v}=2.0 \mathrm{ml} / \mathrm{min}\right)$ to afford compounds $2\left(4.5 \mathrm{mg}, t_{\mathrm{R}}=38.8 \mathrm{~min}\right)$ and $\mathbf{3}\left(5.0 \mathrm{mg}, t_{\mathrm{R}}=29.0 \mathrm{~min}\right)$.

Dimericchalasine $A(1)$ : white amorphous powder; $[\alpha]_{\mathrm{D}}^{25}-131.6(c 0.19, \mathrm{MeOH}) ; \mathrm{ECD}(\mathrm{MeOH}) \lambda_{\max }$ $(\Delta \varepsilon) 238(+4.30), 297(-5.62) \mathrm{nm} ; \mathrm{UV}(\mathrm{MeOH}) \lambda_{\max }(\log \varepsilon) 203$ (4.39) nm; IR (KBr) $v_{\max } 3426,2959$, 2927, 2865, 1722, 1686, 1592, 1439, 1399, 1340, 1245, 1102, 1024, $676 \mathrm{~cm}^{-1} ;{ }^{1} \mathrm{H} \mathrm{NMR}\left(\mathrm{CDCl}_{3}, 600\right.$ $\mathrm{MHz})$ data and ${ }^{13} \mathrm{C} \mathrm{NMR}\left(\mathrm{CDCl}_{3}, 150 \mathrm{MHz}\right)$ data, see Table S1; HRMS (ESI) $\mathrm{m} / z$ : $[\mathrm{M}+\mathrm{Na}]^{+} \mathrm{Calcd}$ for $\mathrm{C}_{48} \mathrm{H}_{68} \mathrm{~N}_{2} \mathrm{O}_{8} \mathrm{Na} 823.4873$; Found 823.4891.

Amichalasine D (2): white amorphous powder, $[\alpha]_{\mathrm{D}}^{25}-7.0(c 0.45, \mathrm{MeOH}) ; \mathrm{ECD}(\mathrm{MeOH}) \lambda(\Delta \varepsilon) 212$ $(+17.0), 255(-7.0), 303(+3.7) \mathrm{nm} ; \mathrm{UV}(\mathrm{MeOH}) \lambda_{\max }(\log \varepsilon)=203(4.60) \mathrm{nm} ; \mathrm{IR}(\mathrm{KBr}) v_{\max }=3434$, 2957, 2929, 1787, 1698, 1630, 1442, 1384, 1349, 1270, 1177, $1028 \mathrm{~cm}^{-1} ;{ }^{1} \mathrm{H}$ NMR (CD $\left.\mathrm{CD}_{3} \mathrm{O}, 800 \mathrm{MHz}\right)$ and ${ }^{13} \mathrm{C}$ NMR $\left(\mathrm{CD}_{3} \mathrm{OD}, 200 \mathrm{MHz}\right)$ data, see Table S2; HRMS (ESI) $m / z$ : $[\mathrm{M}+\mathrm{Na}]^{+}$Calcd for $\mathrm{C}_{57} \mathrm{H}_{72} \mathrm{~N}_{2} \mathrm{O}_{13} \mathrm{Na}$ 1015.4932; Found 1015.4925.

Amichalasine E (3): white amorphous powder; $[\alpha]_{\mathrm{D}}^{25}+17.6(c 0.11, \mathrm{MeOH}) ; \mathrm{ECD}(\mathrm{MeOH}) \lambda_{\max }(\Delta \varepsilon)$ $214(+24.71), 258(-3.08), 296(+6.36) \mathrm{nm}$; UV (MeOH) $\lambda_{\max }(\log \varepsilon) 203$ (4.62) nm; IR (KBr) $v_{\max }$ 3432, 2960, 2929, 2864, 1778, 1699, 1440, 1388, 1260, 1198, 1177, $1047 \mathrm{~cm}^{-1} ;{ }^{1} \mathrm{H}$ NMR $\left(\mathrm{CD}_{3} \mathrm{OD}\right.$, $800 \mathrm{MHz})$ data and ${ }^{13} \mathrm{C}$ NMR $\left(\mathrm{CD}_{3} \mathrm{OD}, 200 \mathrm{MHz}\right)$ data, see Table S2; HRMS (ESI) $m / z:[\mathrm{M}+\mathrm{Na}]^{+}$ Calcd for $\mathrm{C}_{57} \mathrm{H}_{72} \mathrm{~N}_{2} \mathrm{O}_{13} \mathrm{Na}$ 1015.4932; Found 1015.4937.

Crystallographic Data of Compound 1: $\left[2\left(\mathrm{C}_{48} \mathrm{H}_{68} \mathrm{~N}_{2} \mathrm{O}_{8}\right), 3\left(\mathrm{C}_{2} \mathrm{H}_{6} \mathrm{O}\right), 3 \mathrm{O}\right] \mathrm{M}=1788.29$, Orthorhombic, size $0.50 \times 0.10 \times 0.07 \mathrm{~mm}^{3}$, unit cell dimensions a = 12.8171(1) $\AA, \mathrm{b}=23.4866(2) \AA$, $\mathrm{c}=34.8690(3) \AA, \alpha=90.00^{\circ}, \beta=90.00^{\circ}, \gamma=90.00^{\circ}, \mathrm{V}=10496.62(15) \AA^{3}, \mathrm{~T}=100(2) \mathrm{K}$, space group 
$\mathrm{P} 212121, \mathrm{Z}=4, \mathrm{D}_{\mathrm{c}}=1.132 \mathrm{mg} / \mathrm{m}^{3}, \mu=0.635 \mathrm{~mm}^{-1} ; \mathrm{F}(000)=3880$. A total of 54276 reflections were collected in the range $2.268^{\circ}<\theta<73.904^{\circ}$, with 20608 independent reflections $\left[\mathrm{R}_{\mathrm{int}}=0.0311\right.$; completeness to $\theta_{\max }$ was $99.7 \%$. The final $\mathrm{R}$ indices $[\mathrm{I}>2 \sigma(\mathrm{I})], \mathrm{R}_{1}=0.0746, \mathrm{wR}_{2}=0.2271$; $\mathrm{R}$ indices (all data), $\mathrm{R}_{1}=0.0797, \mathrm{wR}_{2}=0.2355$. Flack parameter $=0.07(6)$.

Crystallographic Data of Compound 2: [2( $\left.\left.\mathrm{C}_{57} \mathrm{H}_{72} \mathrm{~N}_{2} \mathrm{O}_{13}\right), 4\left(\mathrm{CH}_{4} \mathrm{O}\right), \mathrm{O}\right] \mathrm{M}=2130.50$, Monoclinic, size $0.15 \times 0.12 \times 0.10 \mathrm{~mm}^{3}$, unit cell dimensions a $=14.66100(10) \AA, \mathrm{b}=13.20340(10) \AA, \mathrm{c}=$ 29.2499(2) $\AA, \alpha=90.00^{\circ}, \beta=90.5210(10)^{\circ}, \gamma=90.00^{\circ}, \mathrm{V}=5661.82(7) \AA^{3}, \mathrm{~T}=100(2) \mathrm{K}$, space group $\mathrm{P} 2_{1}, \mathrm{Z}=4, \mathrm{D}_{\mathrm{c}}=1.250 \mathrm{mg} / \mathrm{m}^{3}, \mu=0.736 \mathrm{~mm}^{-1} ; \mathrm{F}(000)=2288$. A total of 103666 reflections were collected in the range $3.254^{\circ}<\theta<74.064^{\circ}$, with 21419 independent reflections $\left[\mathrm{R}_{\mathrm{int}}=0.0381\right]$; completeness to $\theta_{\max }$ was $99.9 \%$. The final $\mathrm{R}$ indices $[\mathrm{I}>2 \sigma(\mathrm{I})], \mathrm{R}_{1}=0.0512$, $\mathrm{wR}_{2}=0.1382 ; \mathrm{R}$ indices (all data), $\mathrm{R}_{1}=0.0571, \mathrm{wR}_{2}=0.1438$. Flack parameter $=-0.04(5)$.

\section{Pharmacological tests.}

\subsection{Cell lines and cell culture.}

The leukemia cell lines HL-60, THP-1, and U937, were purchased from American Type Culture Collection (VA, USA). Cells were cultured in RPMI-1640 (HyClone, UT, USA), supplemented with $10 \%(\mathrm{v} / \mathrm{v})$ fetal bovine serum. All cells were incubated at $37{ }^{\circ} \mathrm{C}$ in the presence of $5 \% \mathrm{CO}_{2}$ and used for fewer than 6 months after resuscitation.

\subsection{Cytotoxicity assay.}

The cytotoxicity assay was conducted with an MTS kit (Promega, WI, USA) according to the manufacturer's instructions. Briefly, the cells were seeded into 96-well plates at a density of 5000 cells/well and incubated with or without the tested compounds at various concentrations (obtained through serial dilutions). After 48 h, $20 \mu$ Lof MTS was added to each well. The cells were subsequently incubated in the dark for $3 \mathrm{~h}$; then, the optical density of each well was measured at $490 \mathrm{~nm}$ using a plate reader (Bio-Tek Synergy HT, VT, USA). The $50 \%$ inhibitory concentration $\left(\mathrm{IC}_{50}\right)$ for each compound was calculated using SPSS software.

\subsection{Cell cycle analysis.}

After treated with vehicle control or the tested compounds for $30 \mathrm{~h}$, cells were harvested and washed by ice cold PBS, then fixed with $70 \%$ ethanol at $4{ }^{\circ} \mathrm{C}$ for 12 hours. Fixed cells were incubated with 50 $\mu \mathrm{g} / \mathrm{mL}$ propidium iodide in the presence of $100 \mu \mathrm{g} / \mathrm{mL}$ RNAase and $0.2 \%$ Triton $\mathrm{X}-100$ at least 30 min. The DNA content of the cells was measured on a FACScan Cytometer (Becton Dickinson San 
Jose, CA, USA) and cell cycle distribution was determined.

\subsection{Apoptosis analysis.}

A FITC-Annexin V/PI apoptosis detection kit (Zoman Biotechnology, Beijing, China) was used to evaluate the apoptotic induction effects of the tested compounds. Briefly, cells were exposed to vehicle control (DMSO, $<0.1 \%$ ) or the tested compounds for $48 \mathrm{~h}$. After that, cells were harvested and washed with PBS and resuspended in binding buffer with Annexin V-FITC and PI. After 15 minutes, the cells were analyzed by flow cytometry (Becton Dickinson, CA, USA).

\subsection{Western blotting analysis.}

Cells were treated with vehicle control $(\mathrm{DMSO},<0.1 \%)$ or the tested compounds, and then lysed in RIPA (Beyotime Biotechnology, Shanghai, China) lysate buffer, the protein concentrations were quantified with BCA (bicinchoninic acid) protein assay reagents.

Protein concentrations were determined and equalized before loading. Equal amounts of protein were denatured and subjected to electrophoresis in 10\% SDS-PAGE gels and then transferred to PVDF membrane. Immunoblotting was performed using the indicated primary antibodies (Cell Signaling Technology, MA, USA) and HRP conjugated anti-rabbit IgG. Protein bands were detected by chemiluminescent substrates and visualized using GeneGnome5 imaging and analysis systems. 


\section{HRESIMS spectrum of compound 1}

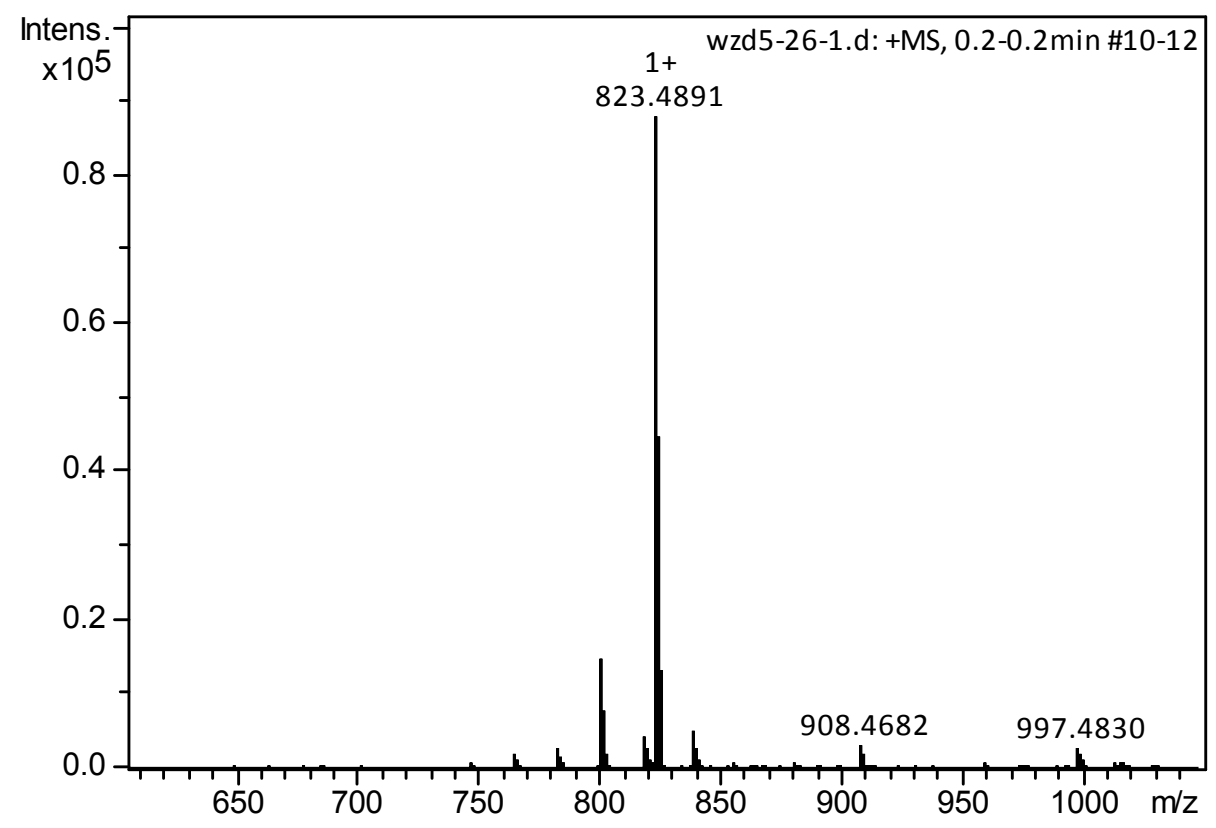

\section{UV spectrum of compound 1}

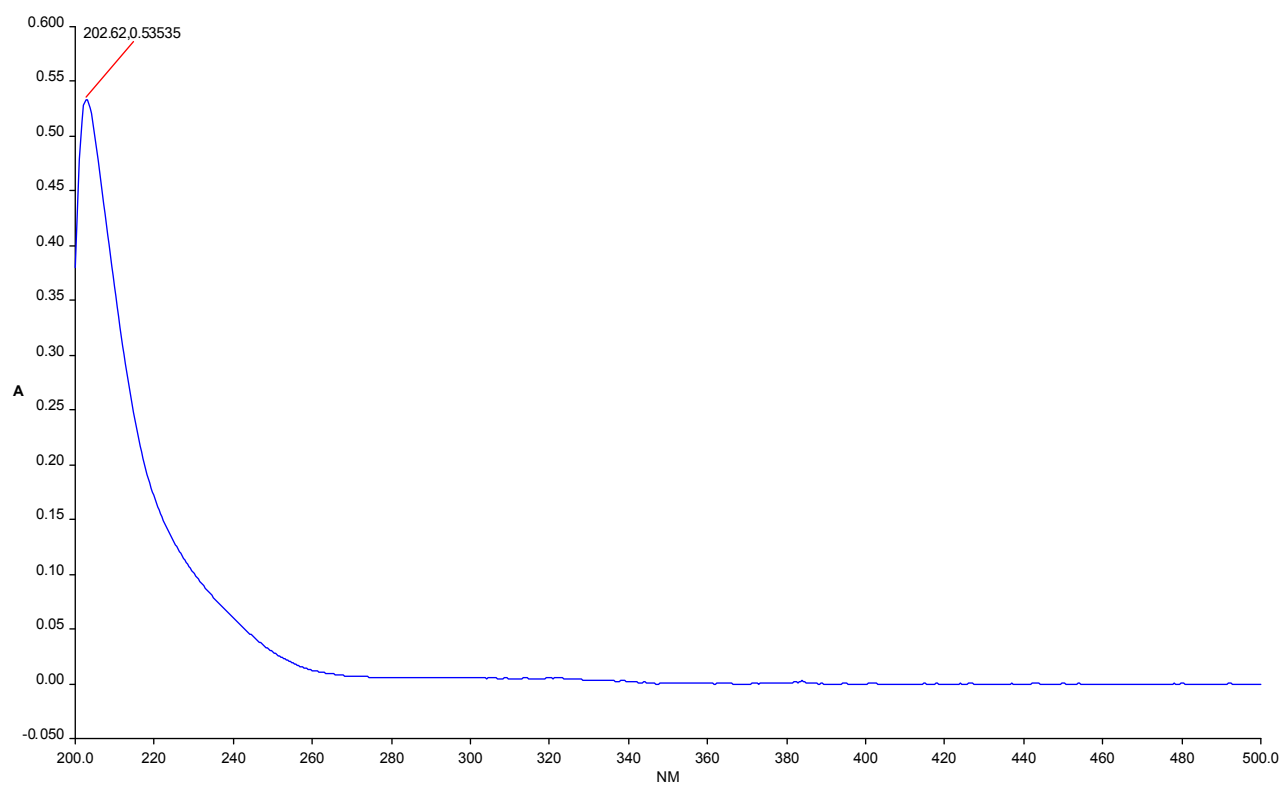


IR spectrum of compound 1

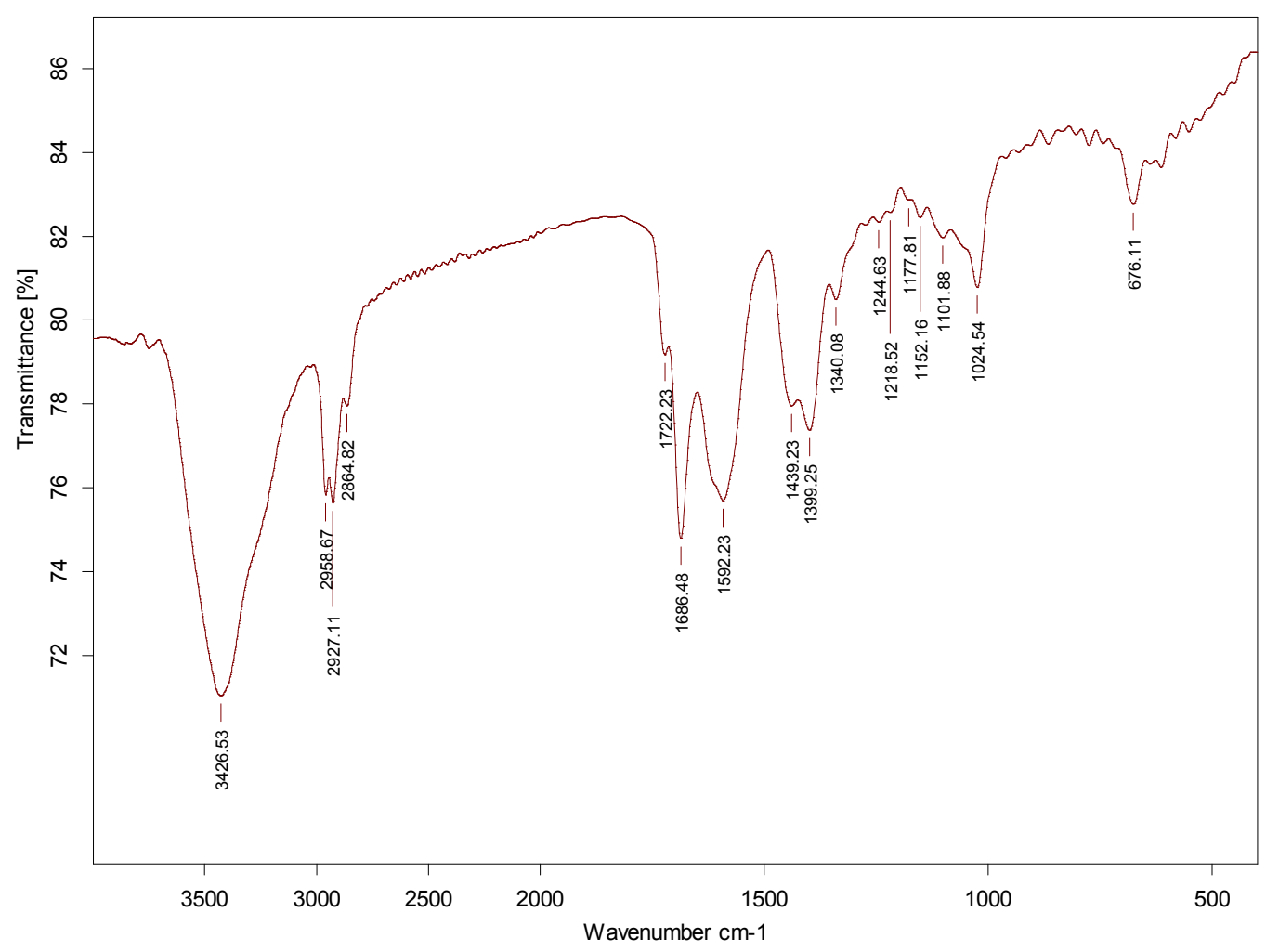

${ }^{1} \mathrm{H}$ NMR spectrum of compound 1 (in $\mathrm{CDCl}_{3}, 600 \mathrm{MHz}$ )

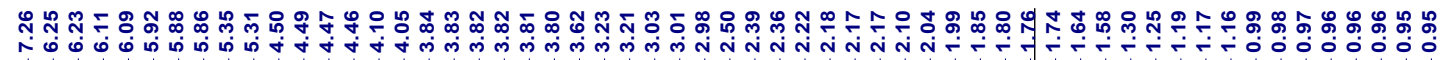

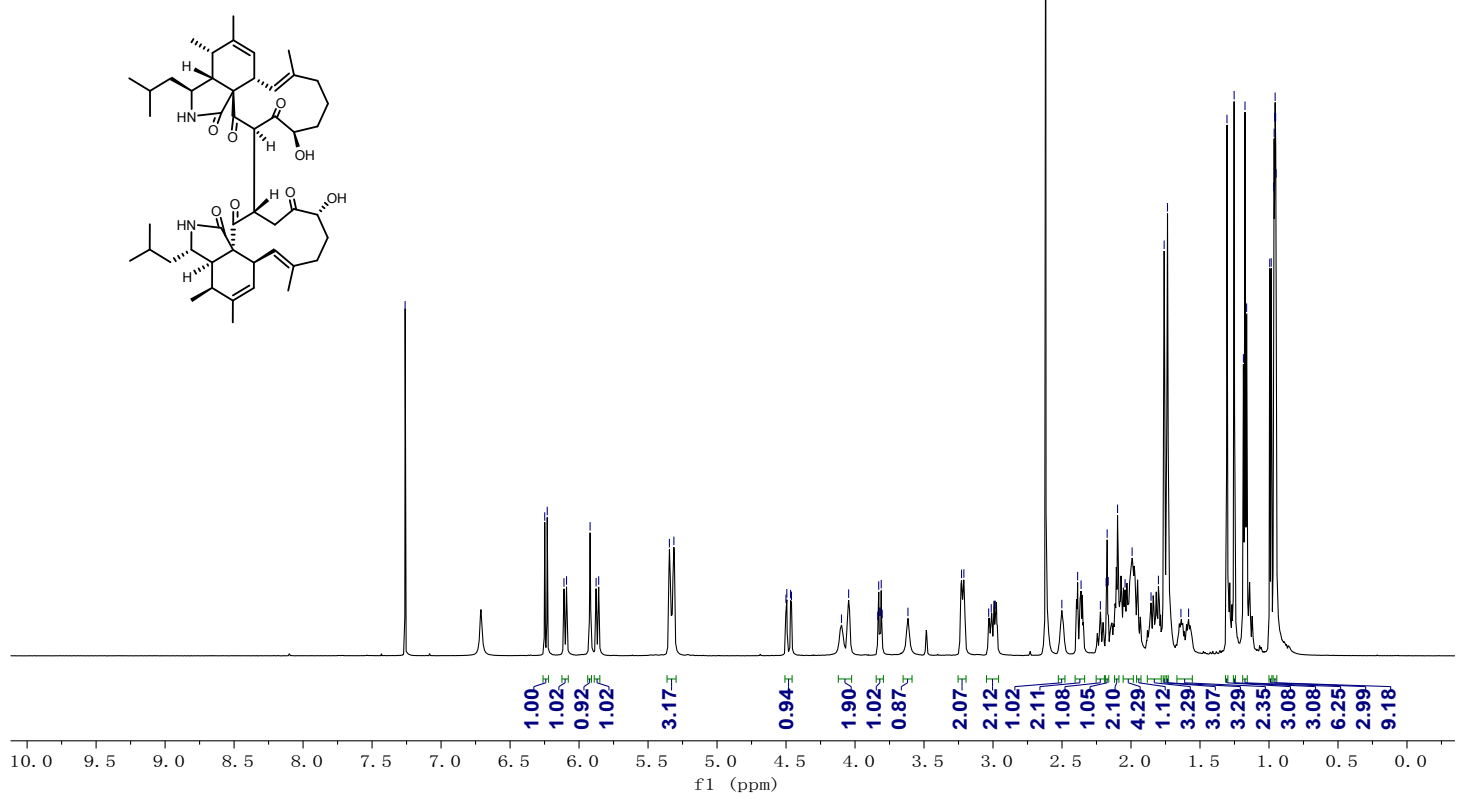




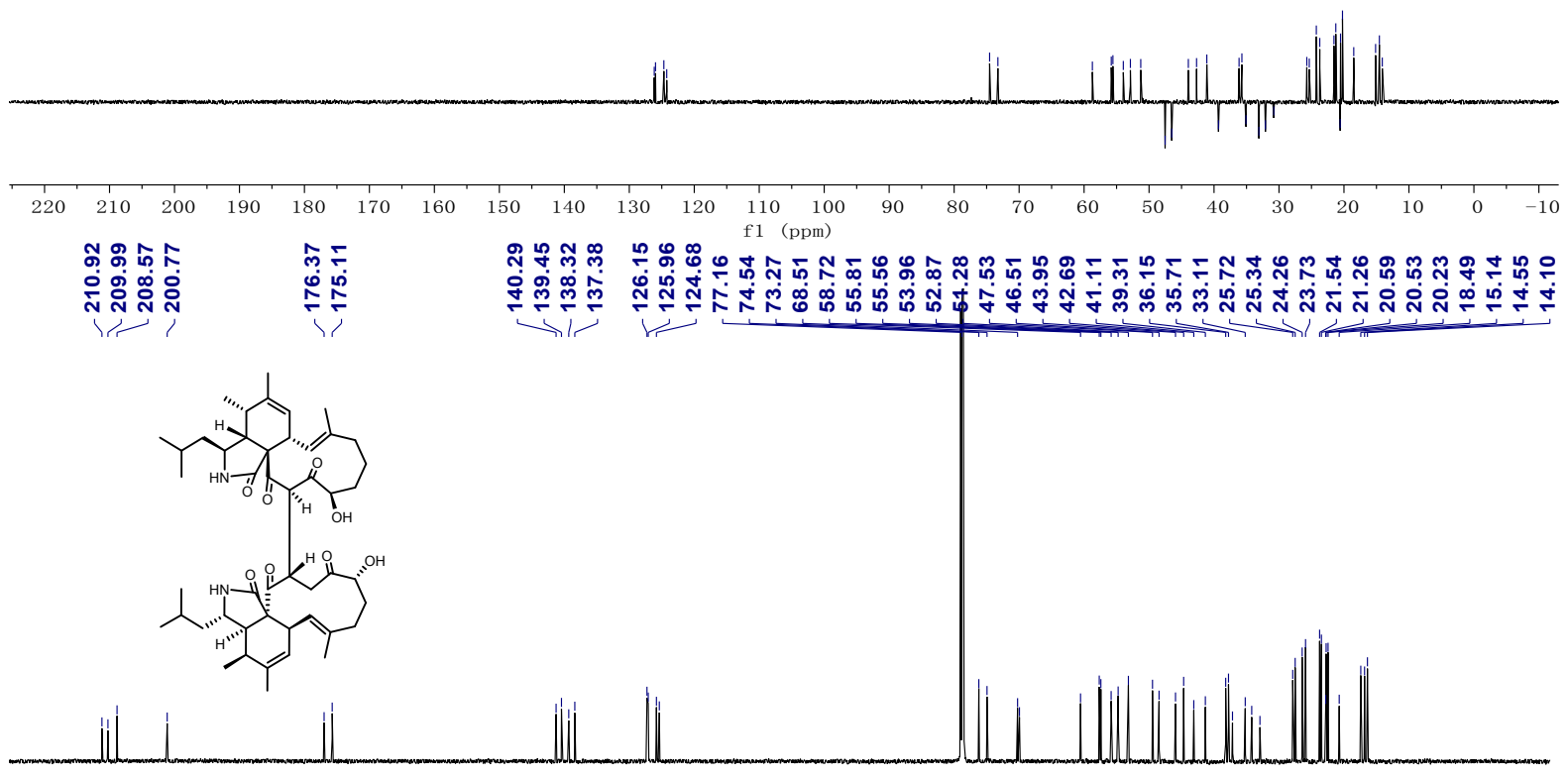

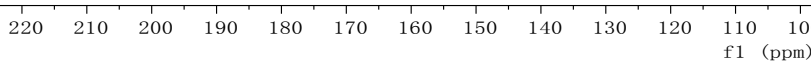

HSQC spectrum of compound 1 (in $\mathrm{CDCl}_{3}, 600 \mathrm{MHz}$ )

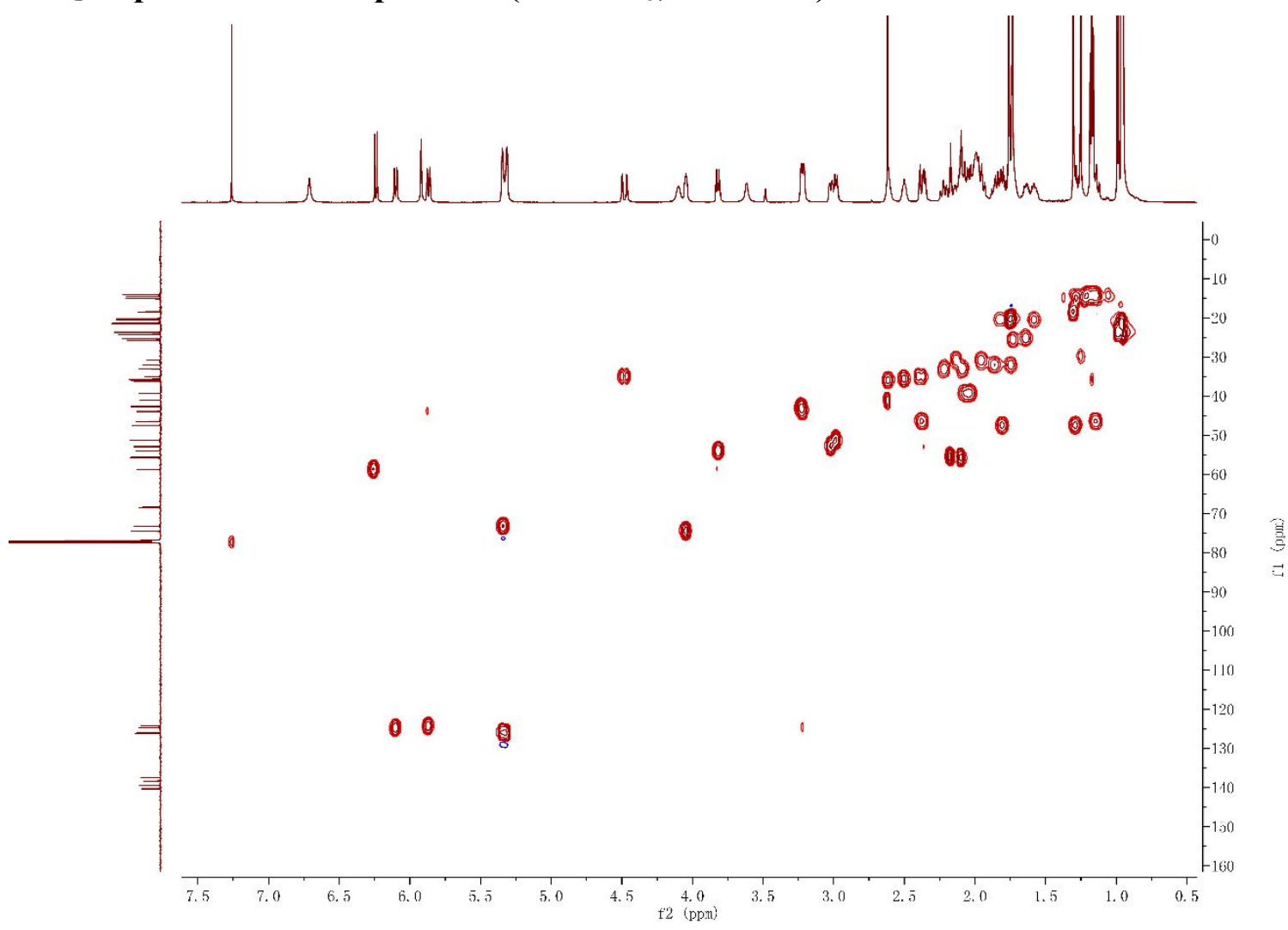


$\mathrm{HMBC}$ spectrum of compound 1 (in $\mathrm{CDCl}_{3}, 600 \mathrm{MHz}$ )

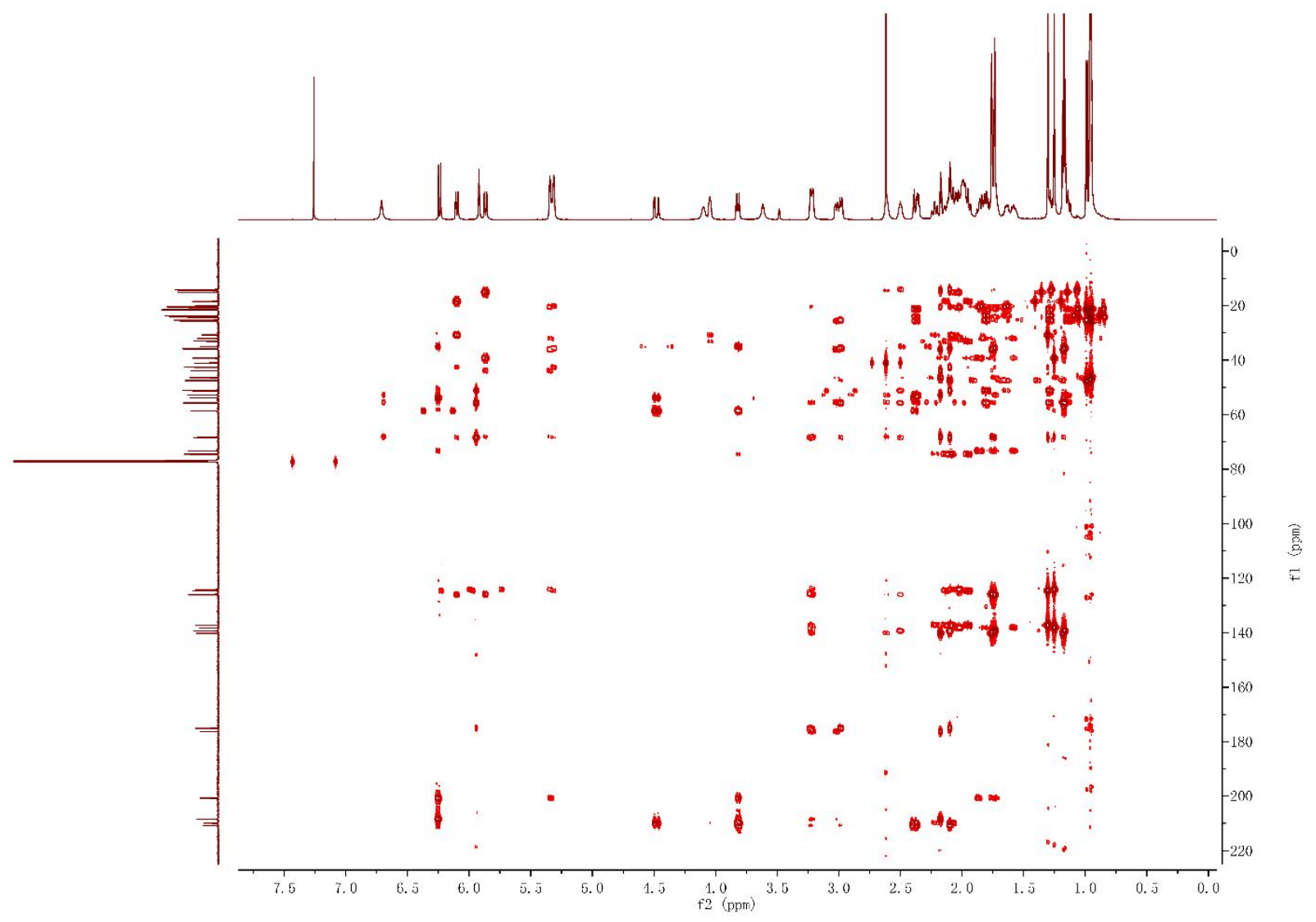

${ }^{1} \mathrm{H}^{-1} \mathrm{H}$ COSY spectrum of compound 1 (in $\mathrm{CDCl}_{3}, 600 \mathrm{MHz}$ )

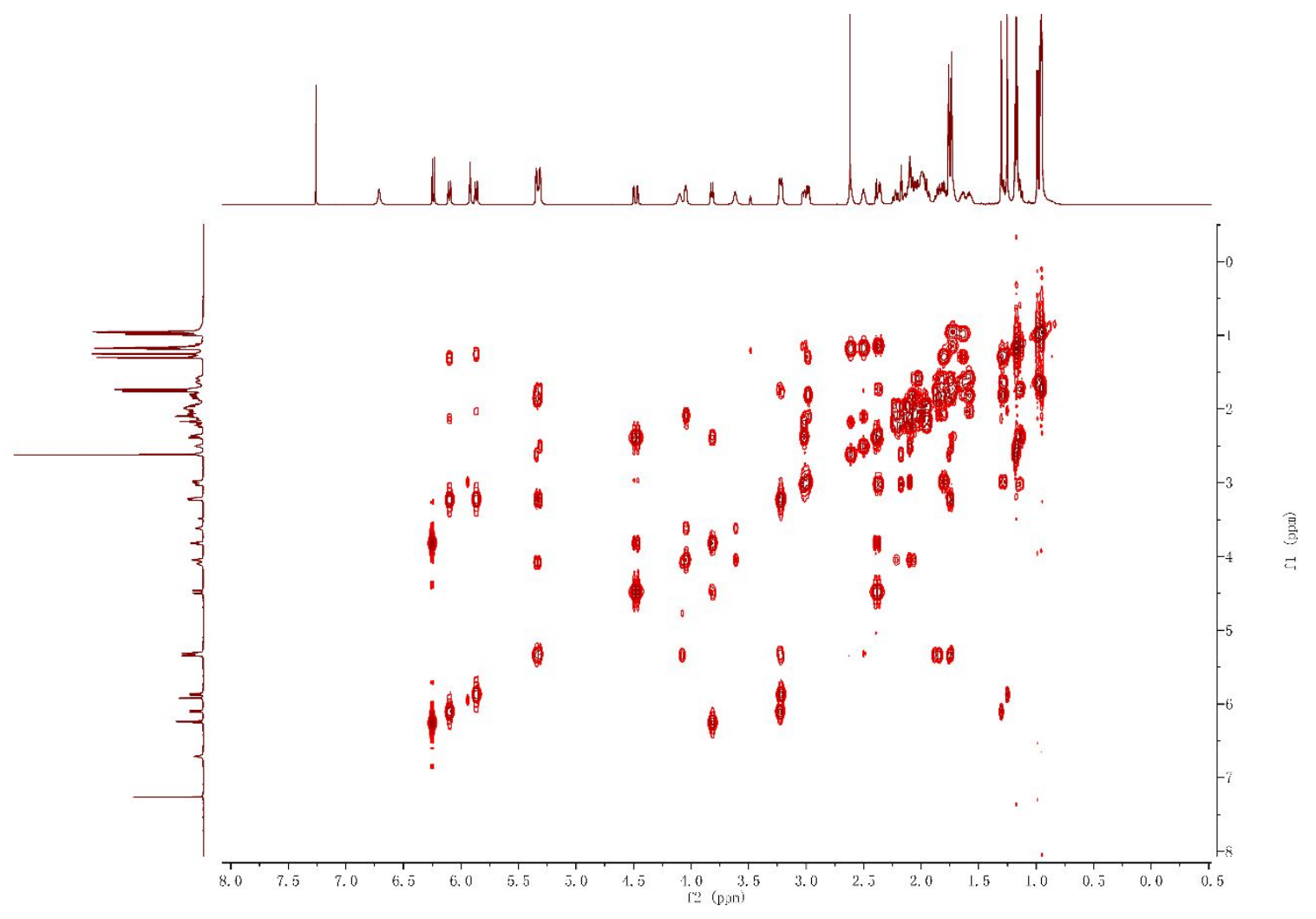


ROESY spectrum of compound 1 (in $\mathrm{CDCl}_{3}, 600 \mathrm{MHz}$ )

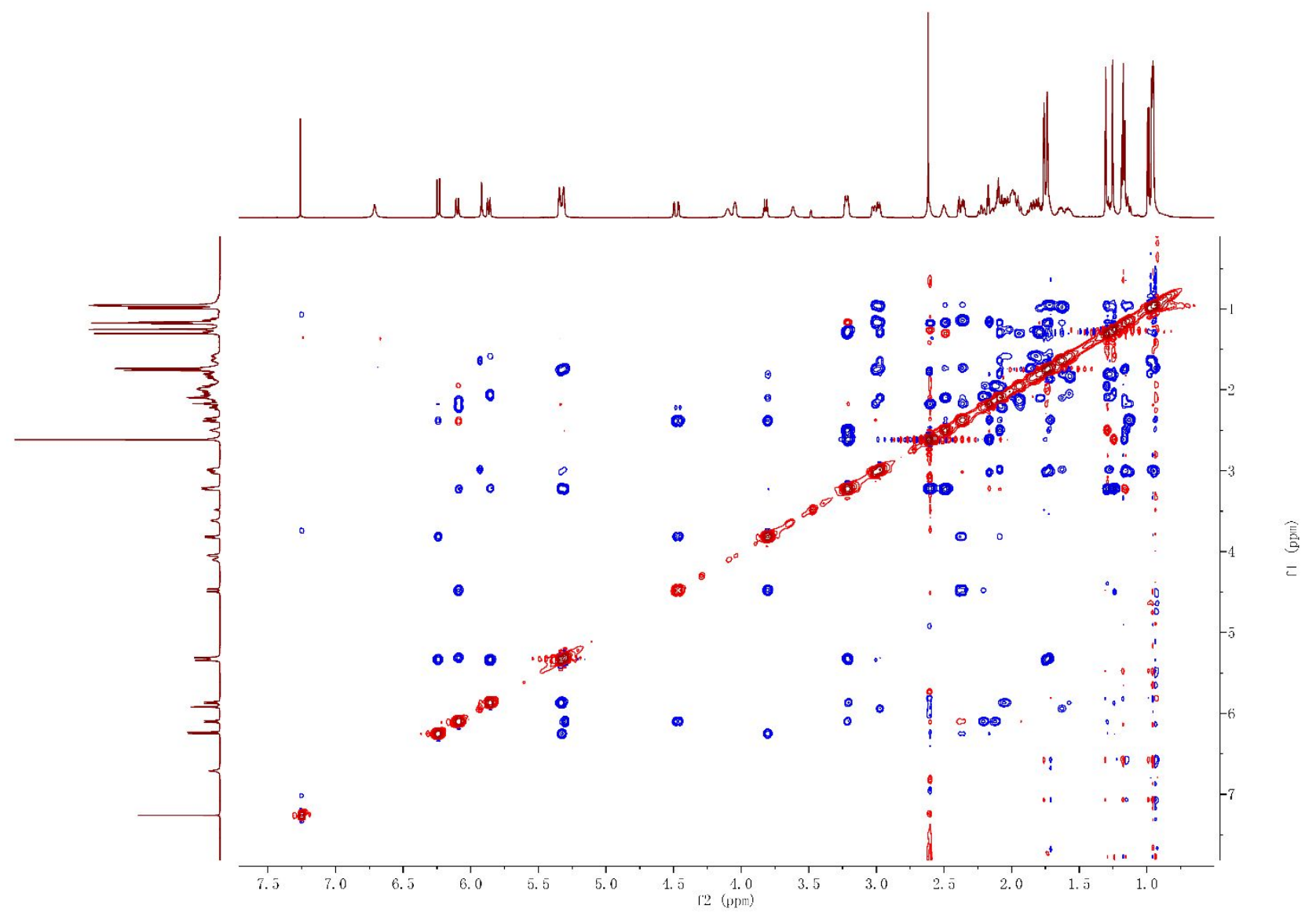

HRESIMS spectrum of compound 2

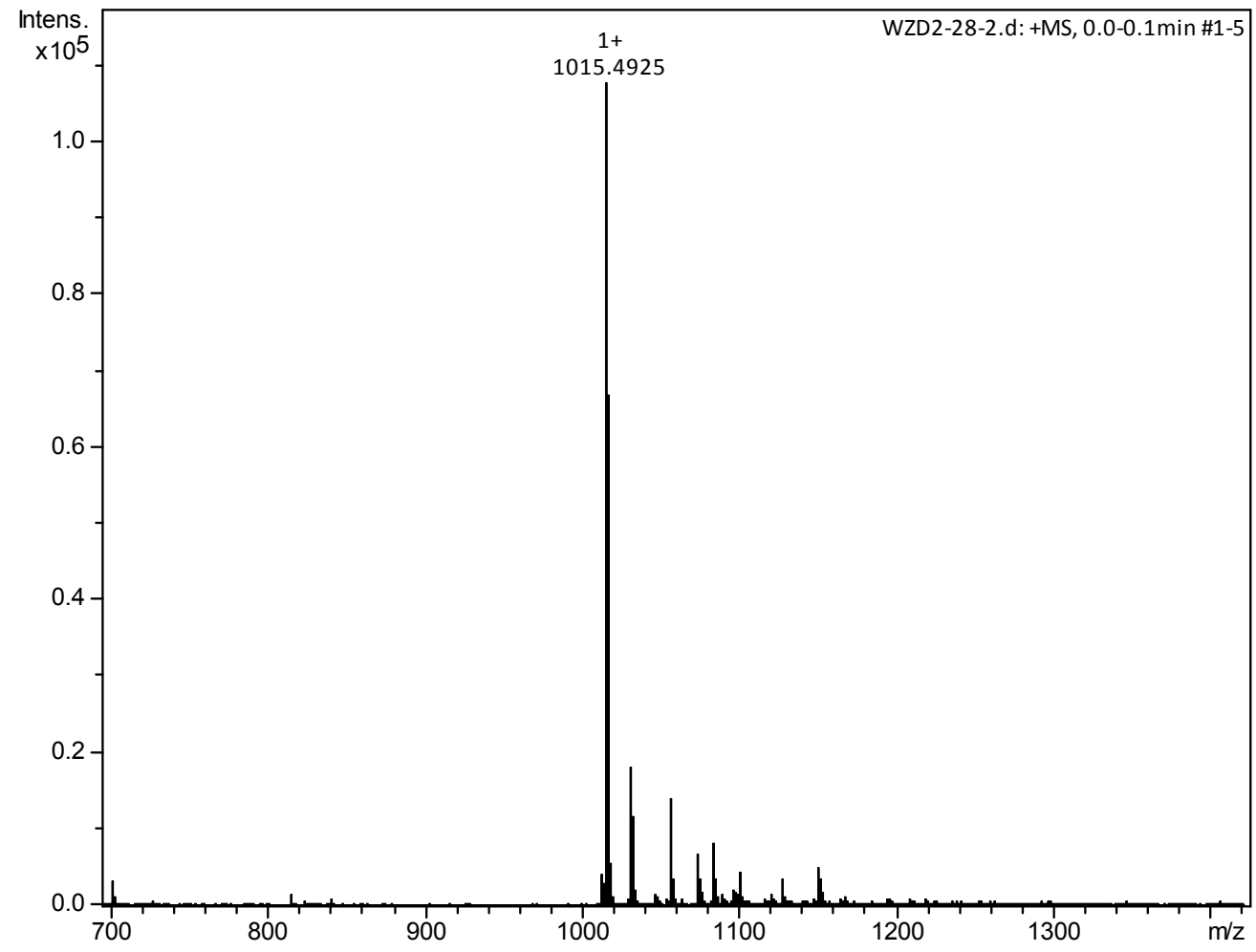


UV spectrum of compound 2

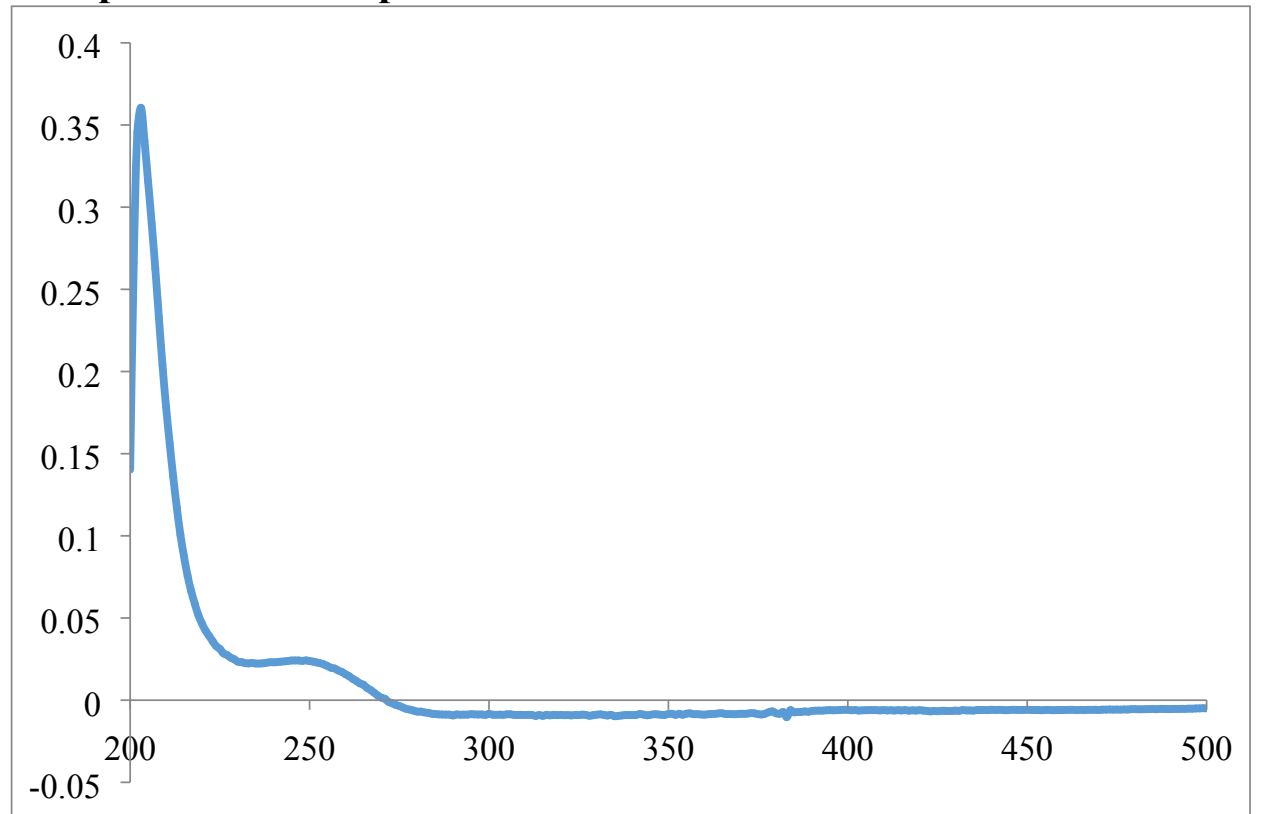

IR spectrum of compound 2

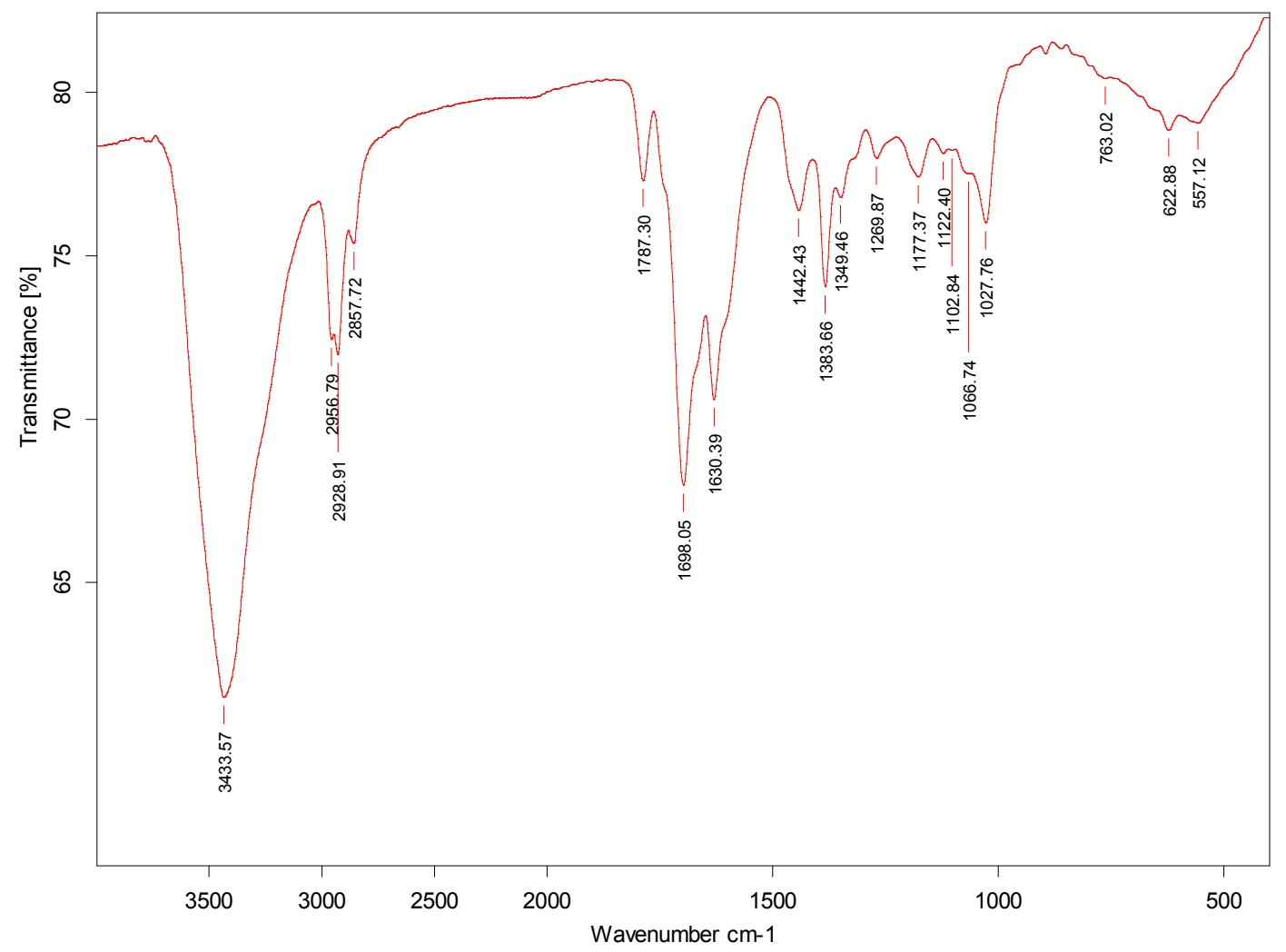



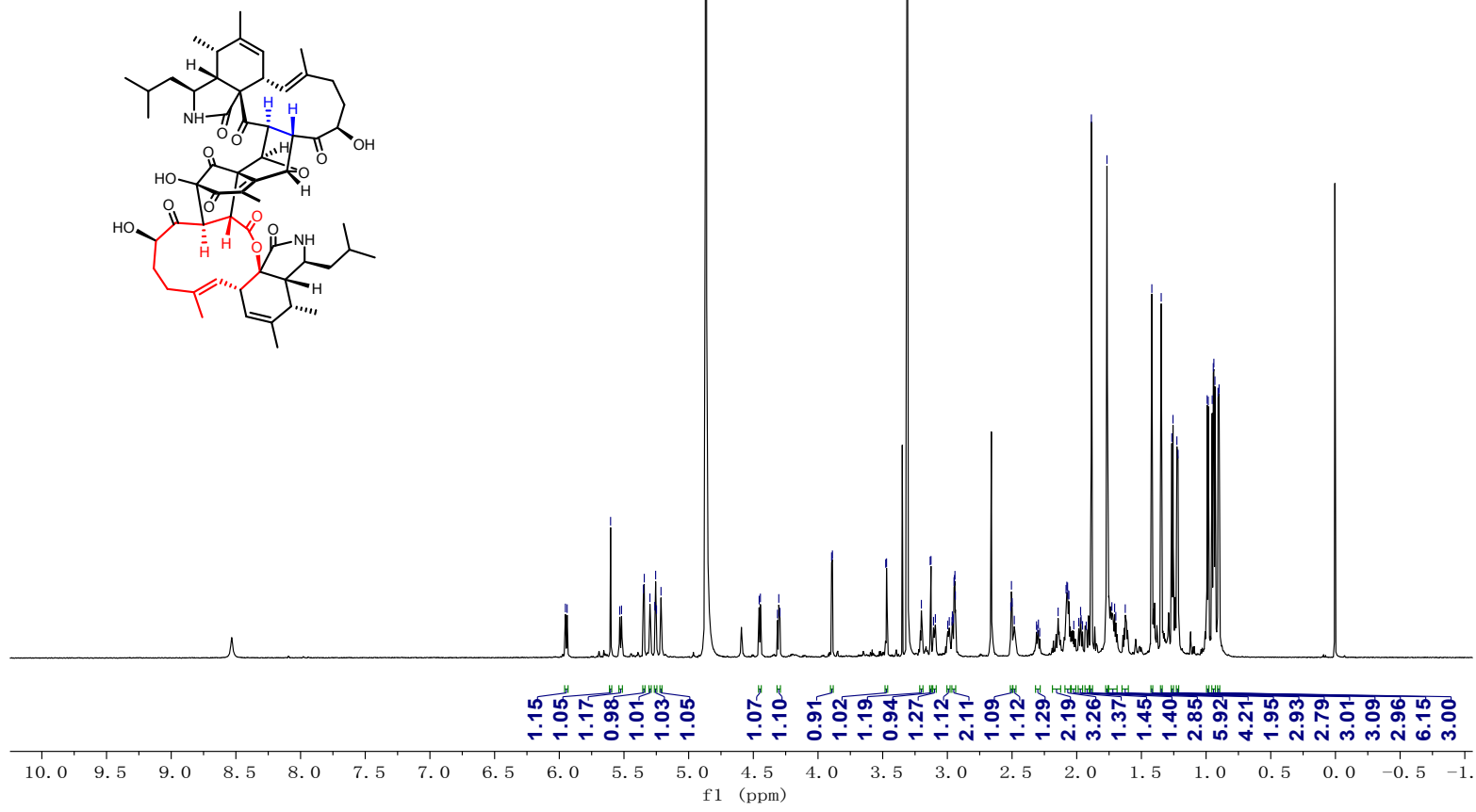

${ }^{13} \mathrm{C}$ NMR and DEPT spectra of compound 2 (in $\mathrm{CD}_{3} \mathrm{OD}, 200 \mathrm{MHz}$ )

象员

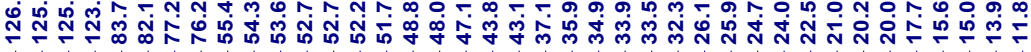
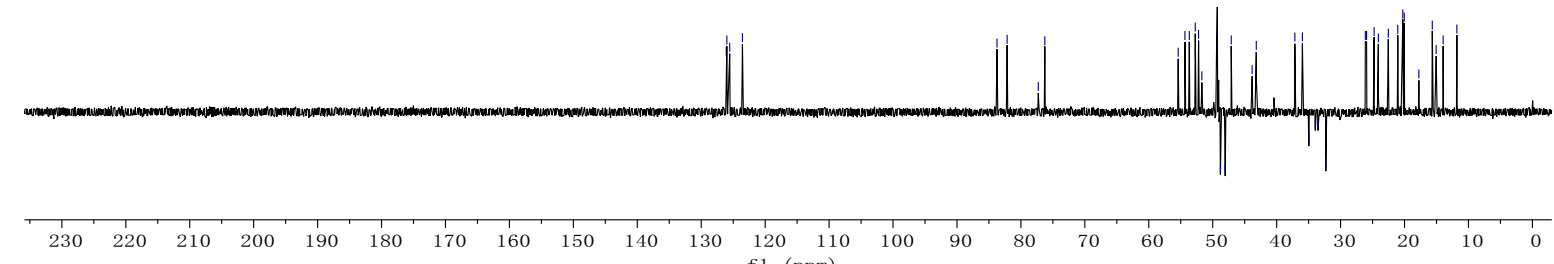

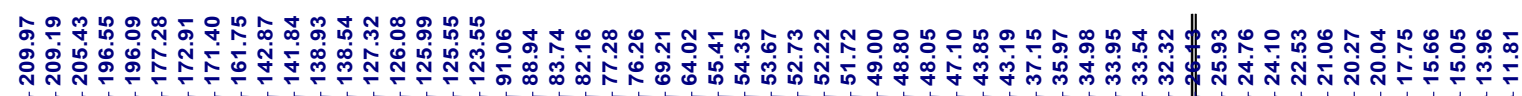

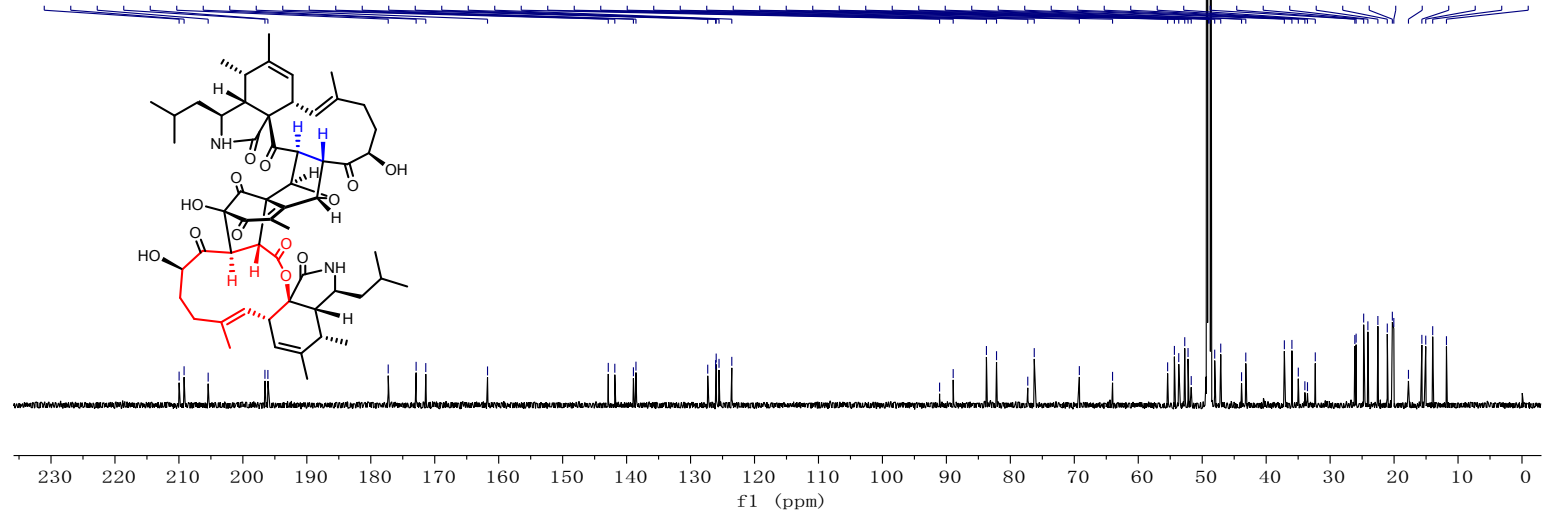


HSQC spectrum of compound 2 (in $\mathrm{CD}_{3} \mathrm{OD}, 800 \mathrm{MHz}$ )

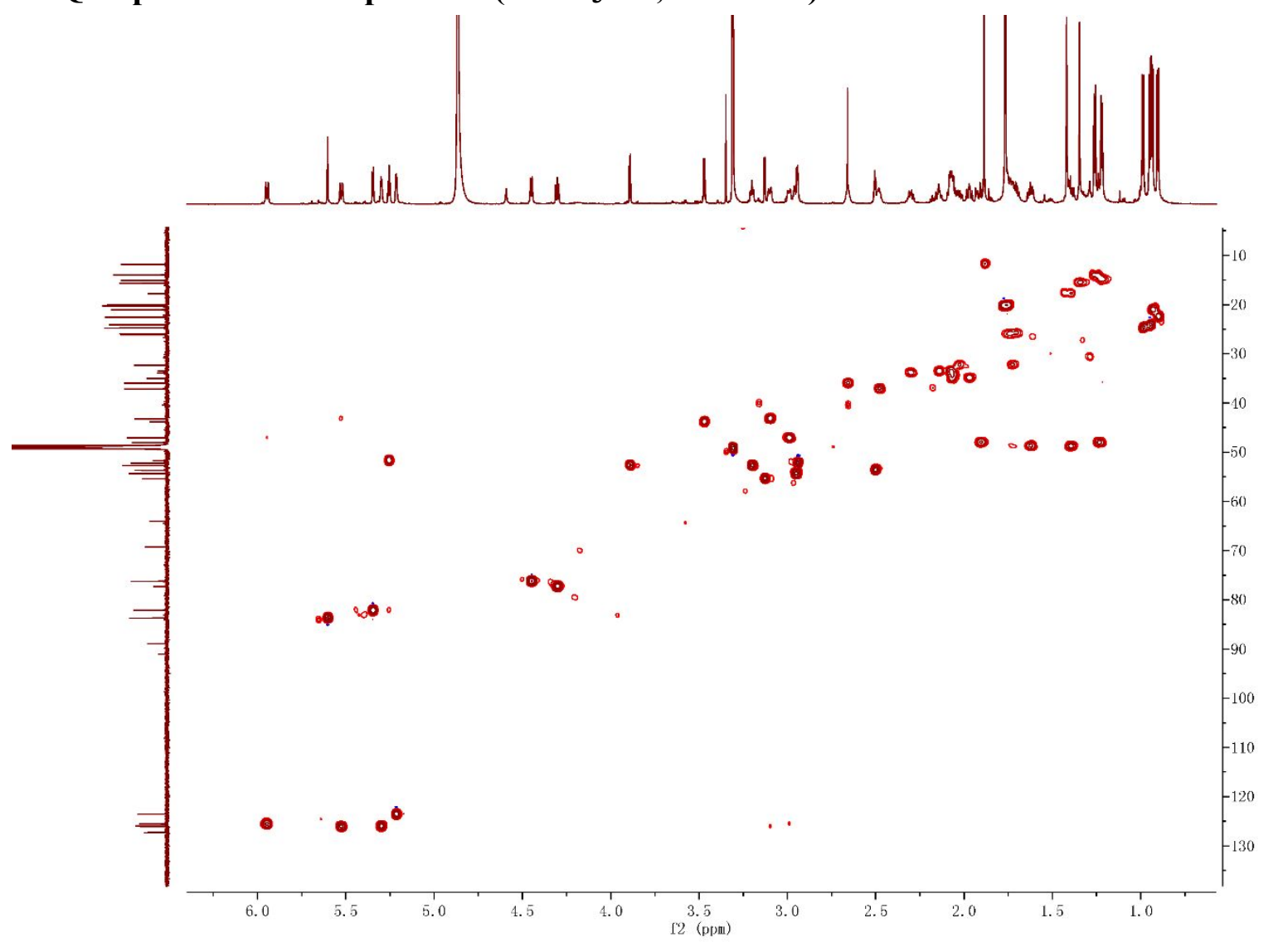

HMBC spectrum of compound 2 (in $\mathrm{CD}_{3} \mathrm{OD}, 800 \mathrm{MHz}$ )

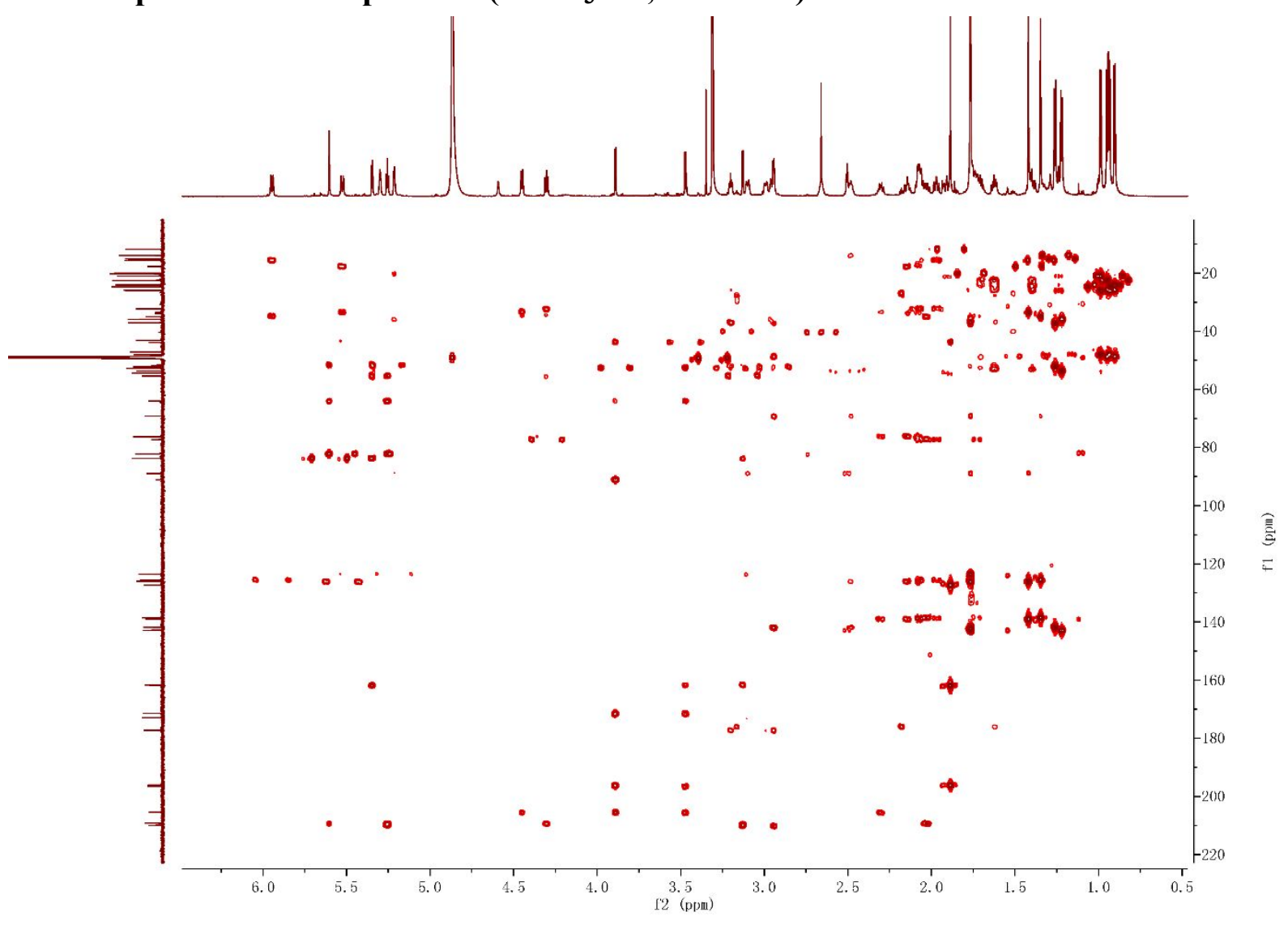


${ }^{1} \mathrm{H}^{-1} \mathrm{H}$ COSY spectrum of compound 2 (in $\mathrm{CD}_{3} \mathrm{OD}, 800 \mathrm{MHz}$ )

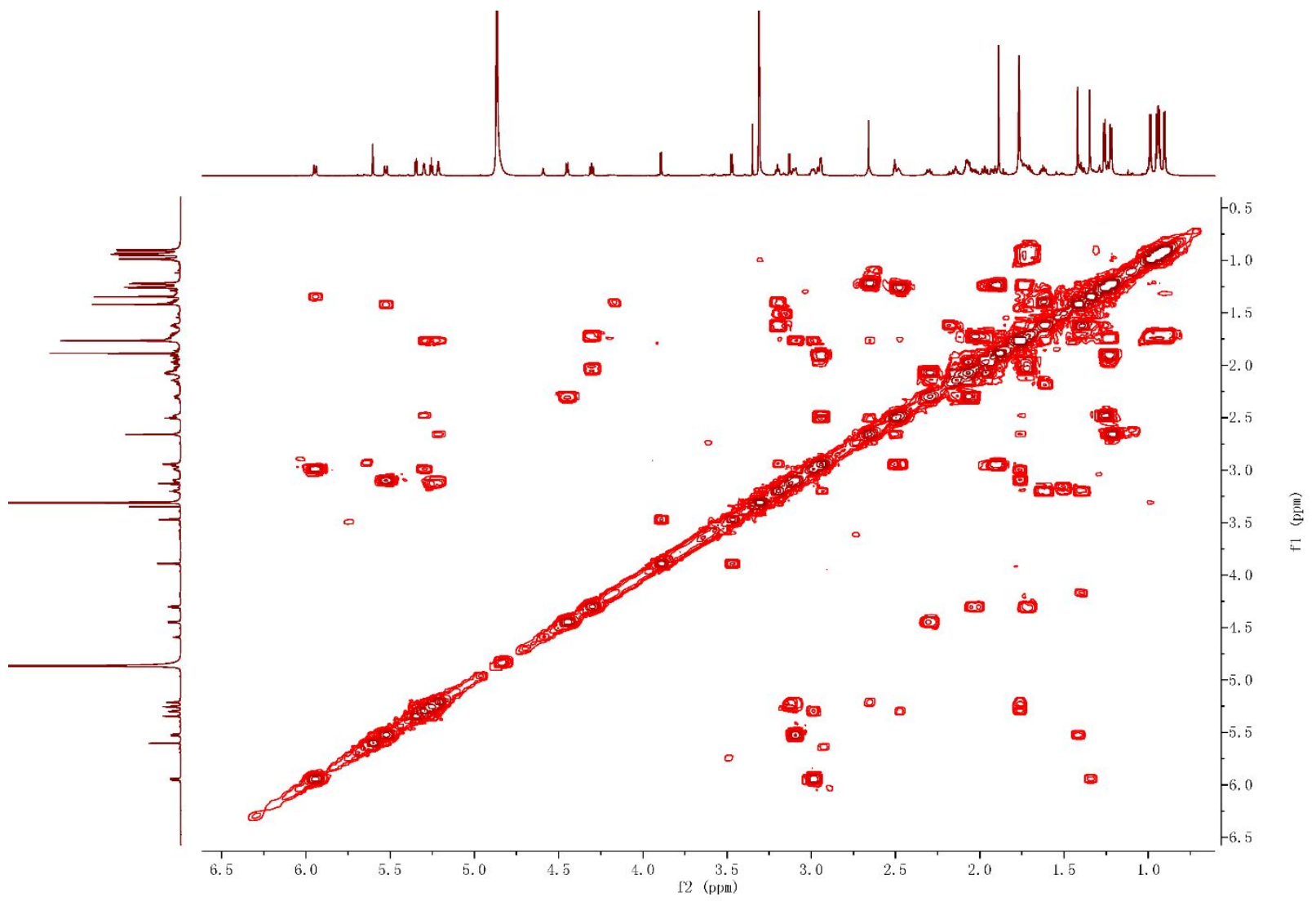

ROESY spectrum of compound 2 (in $\mathrm{CD}_{3} \mathrm{OD}, 800 \mathrm{MHz}$ )

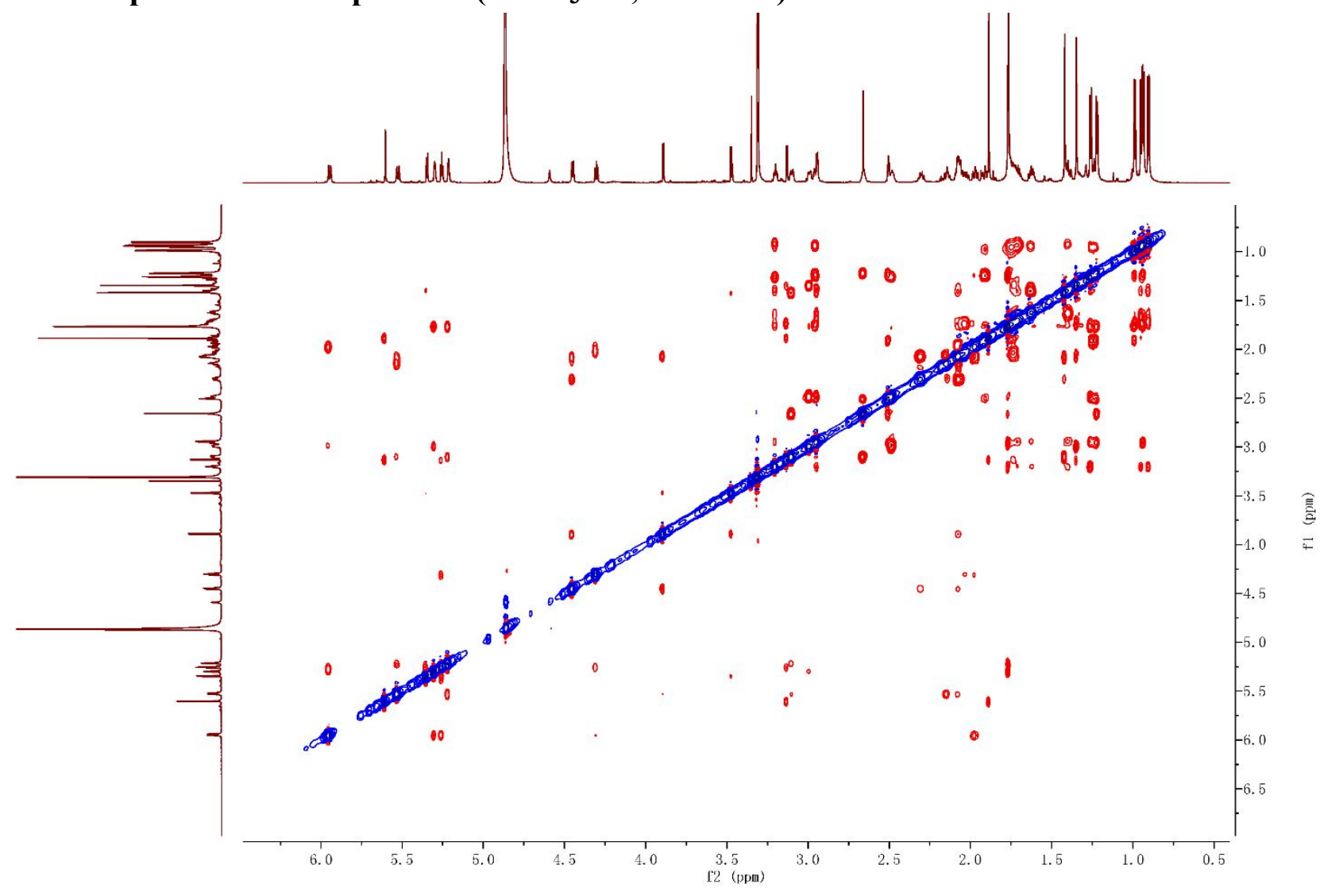




\section{HRESIMS spectrum of compound 3}

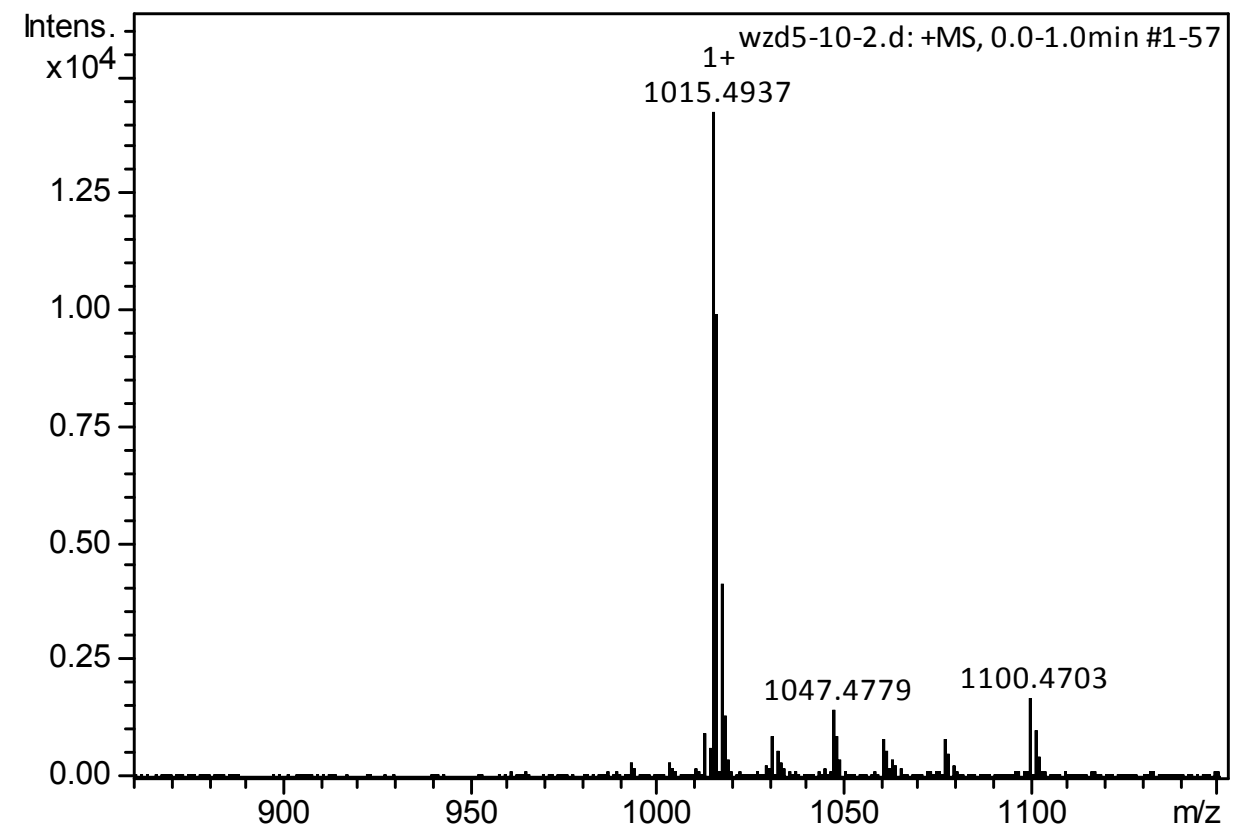

UV spectrum of compound 3

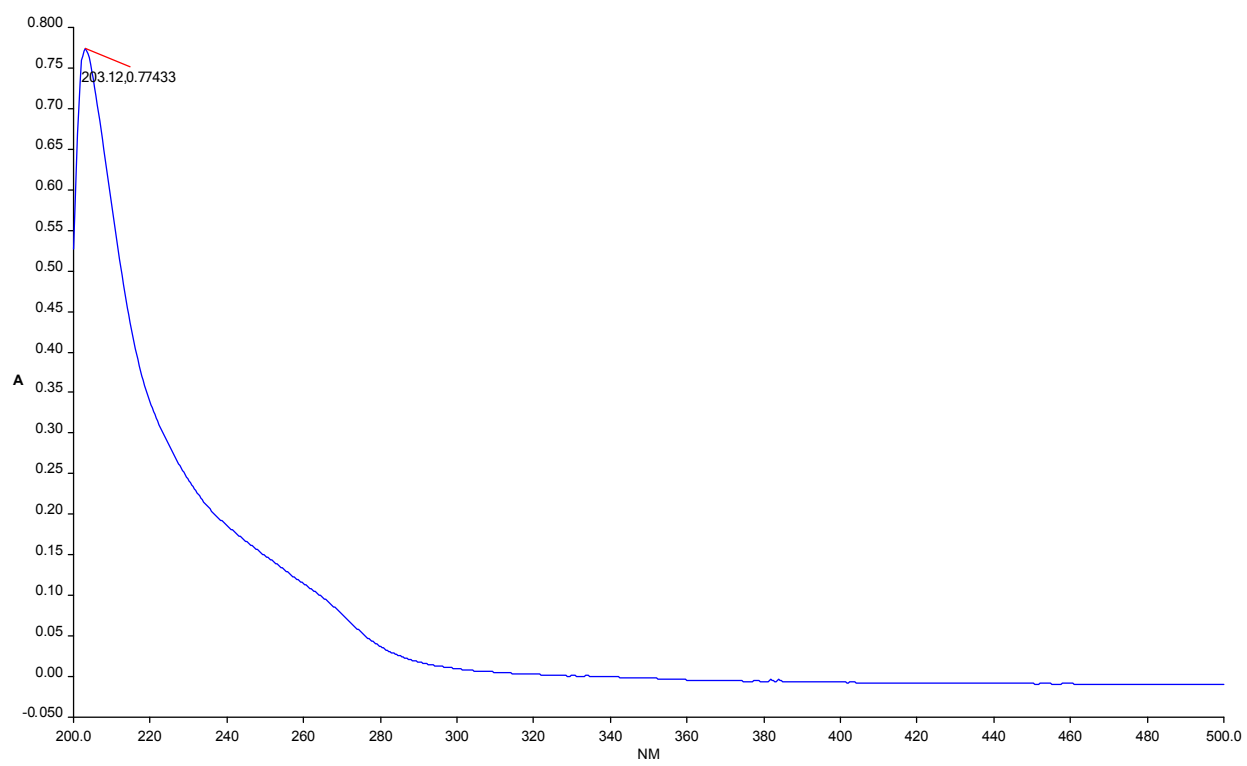


IR spectrum of compound 3

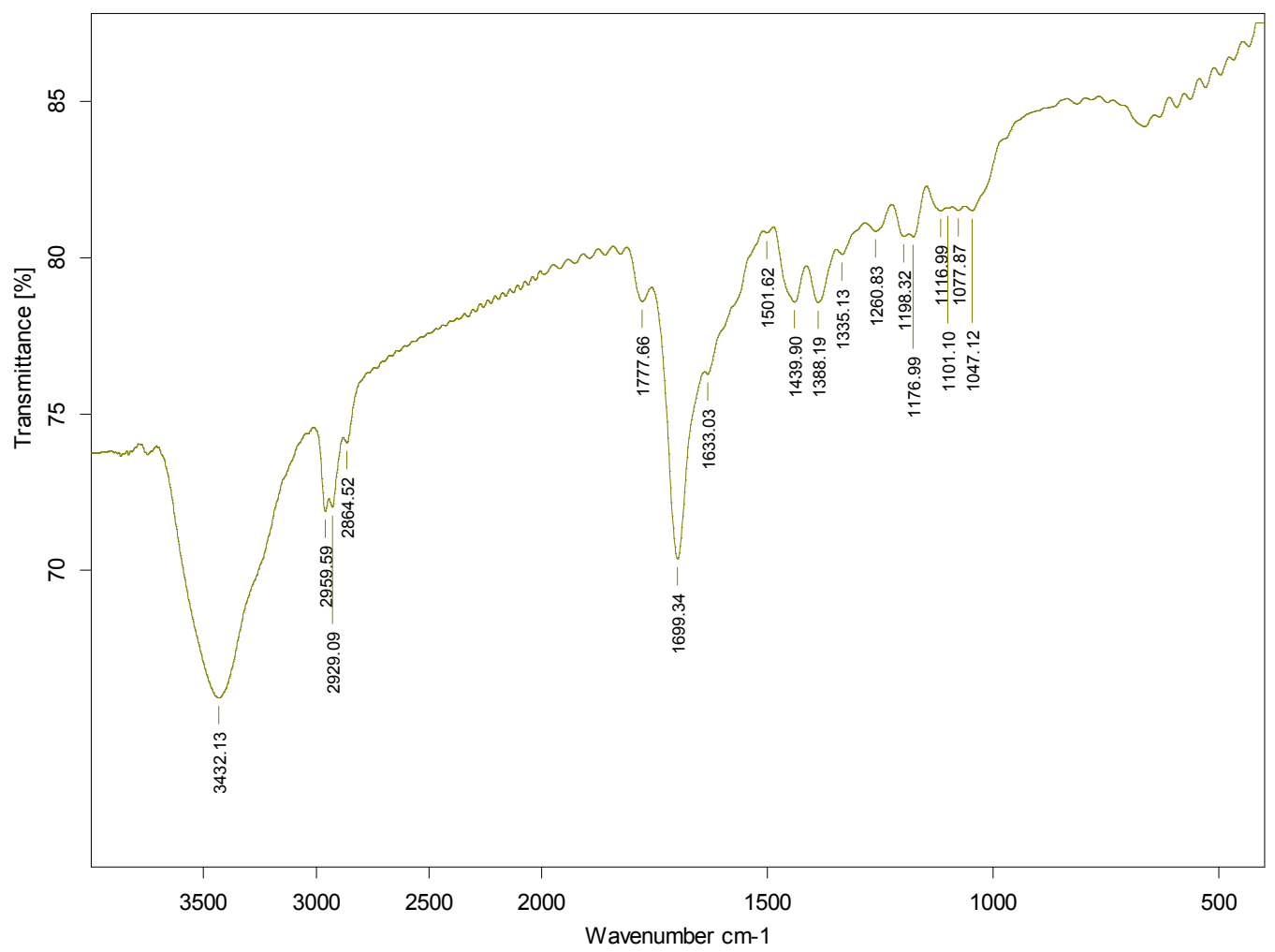

${ }^{1} \mathrm{H}$ NMR spectrum of compound 3 (in $\mathrm{CD}_{3} \mathrm{OD}, 800 \mathrm{MHz}$ )

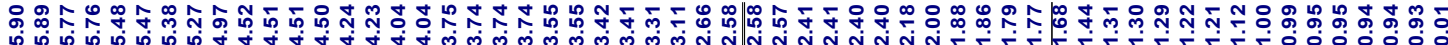

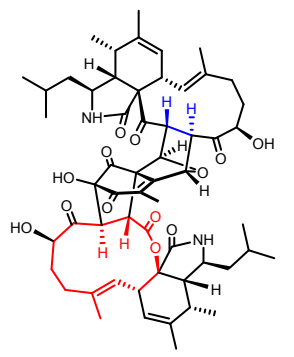




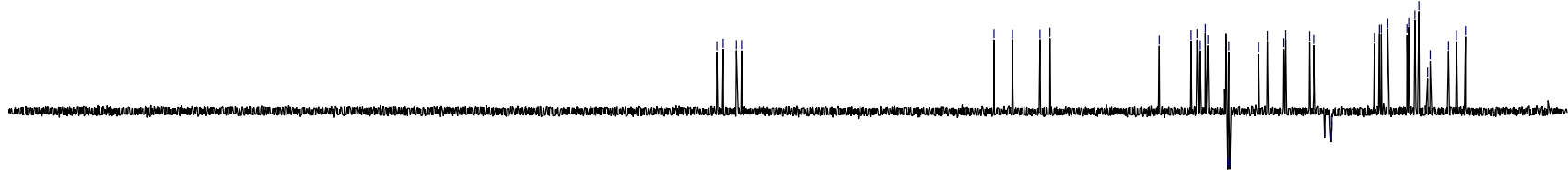

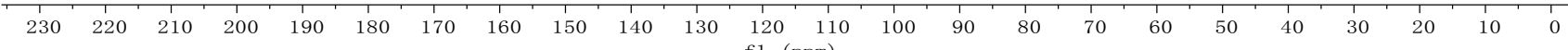

๓

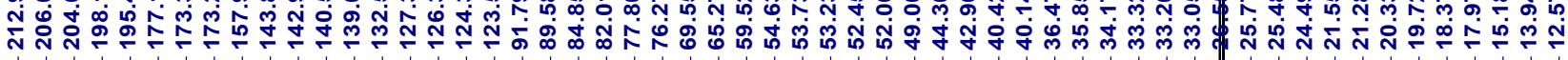
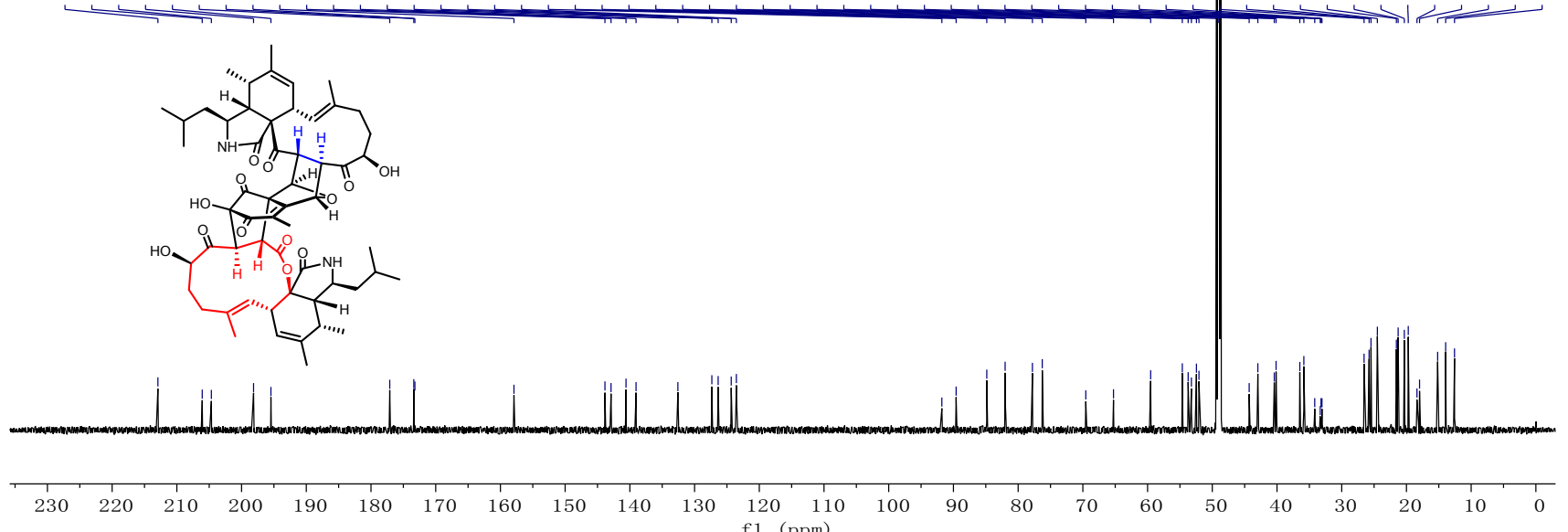

HSQC spectrum of compound 3 (in $\mathrm{CD}_{3} \mathrm{OD}, 800 \mathrm{MHz}$ )

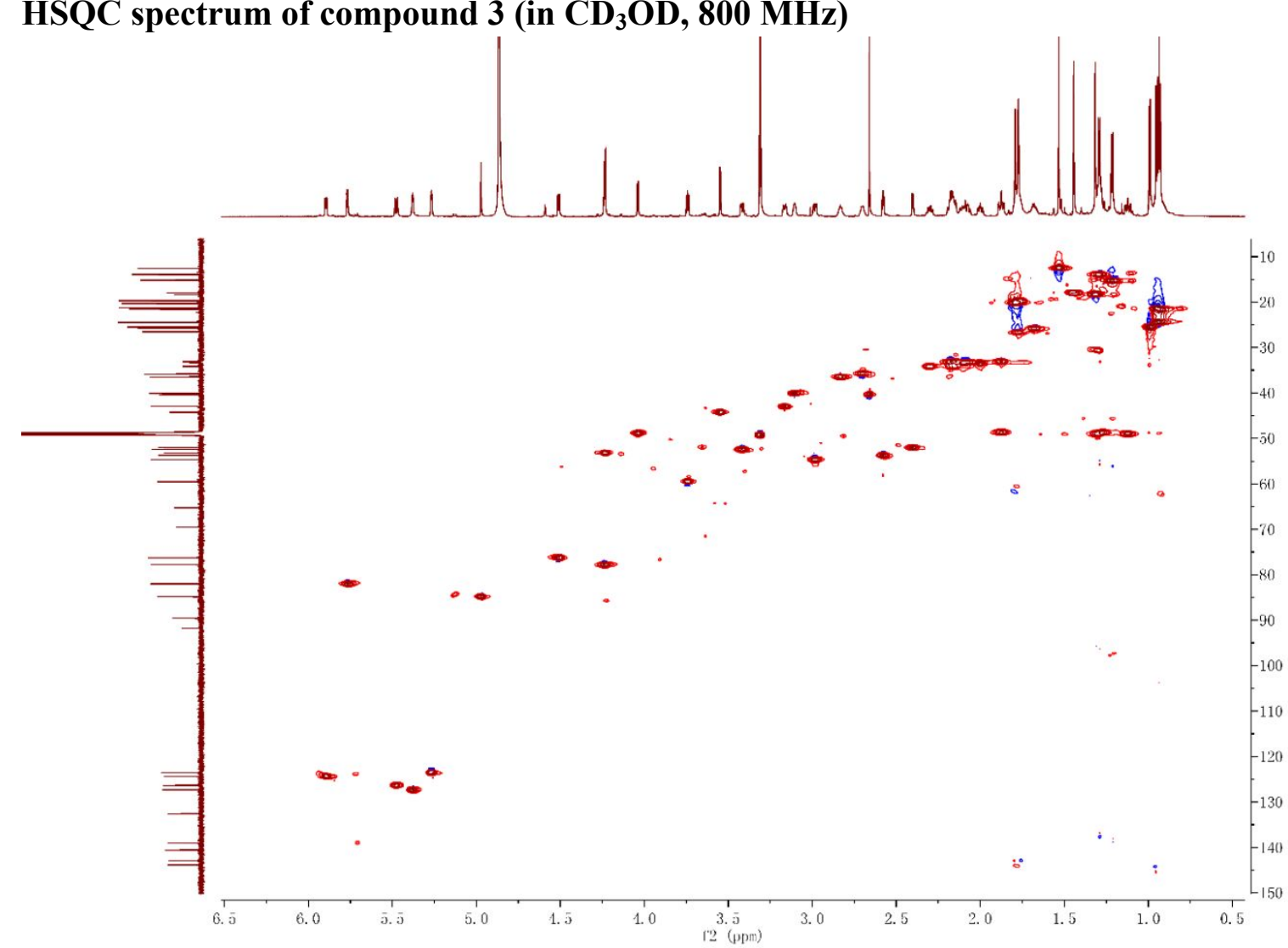


HMBC spectrum of compound 3 (in $\mathrm{CD}_{3} \mathrm{OD}, 800 \mathrm{MHz}$ )

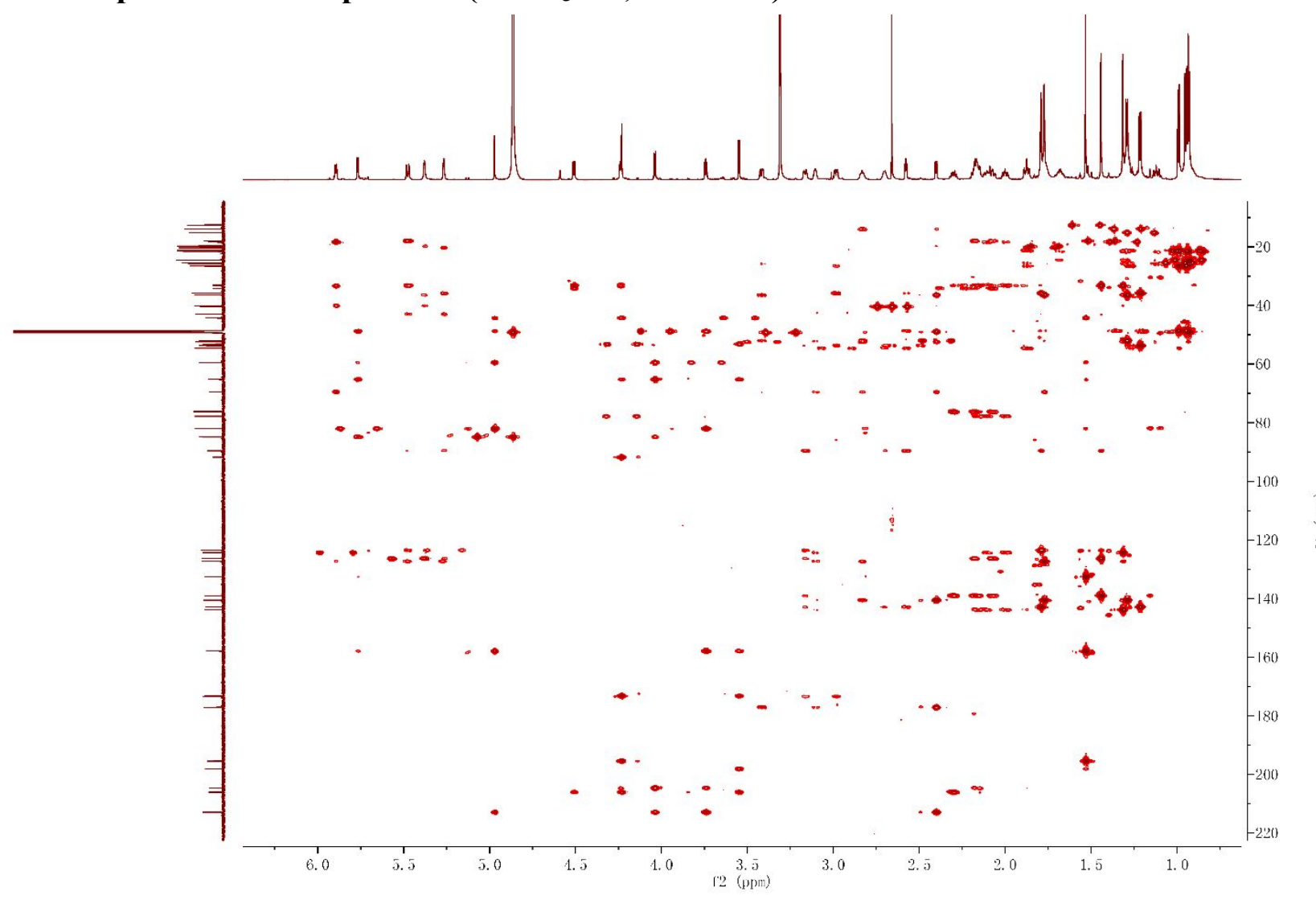

${ }^{1} \mathrm{H}^{-1} \mathrm{H}$ COSY spectrum of compound 3 (in $\mathrm{CD}_{3} \mathrm{OD}, 800 \mathrm{MHz}$ )

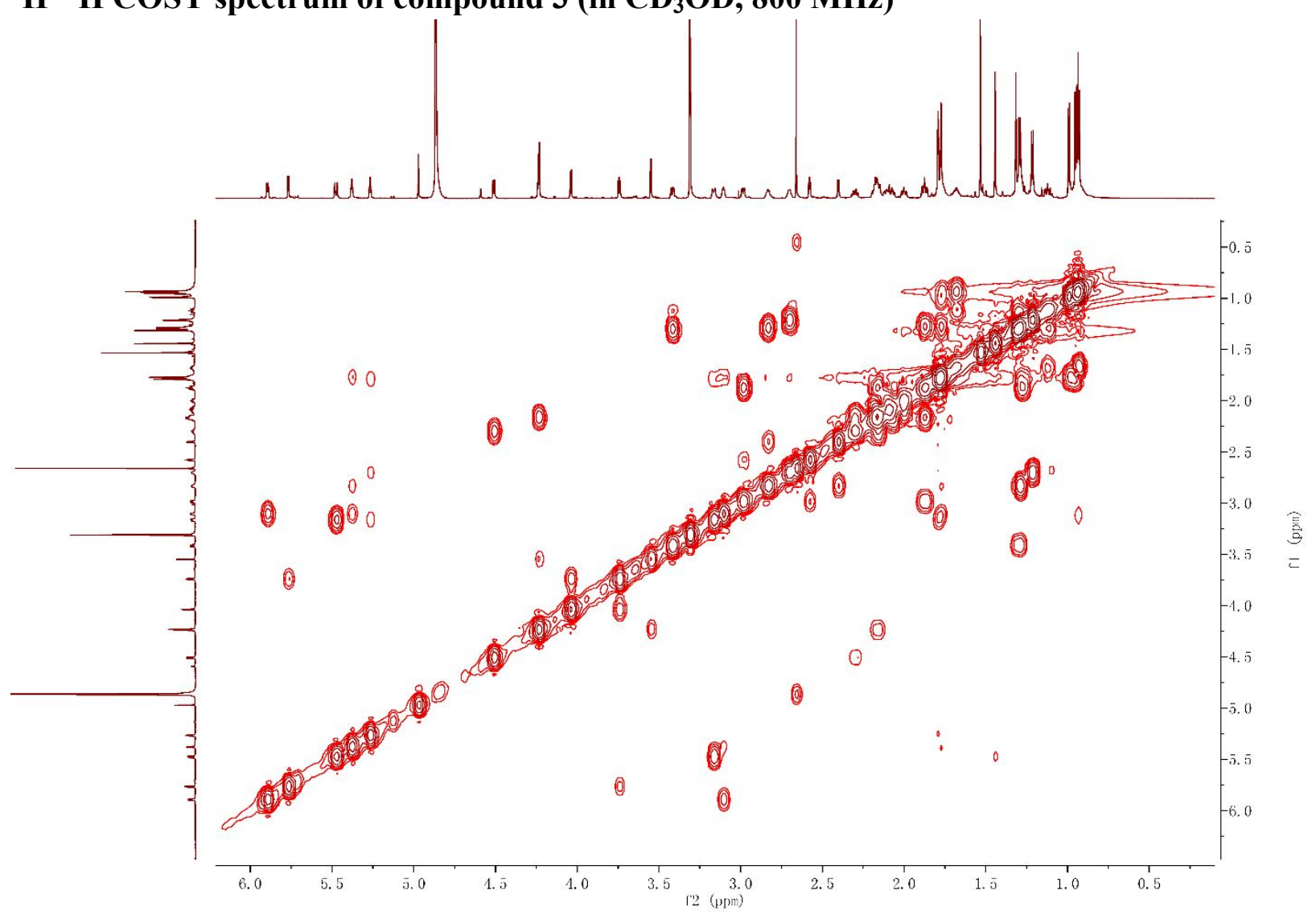


ROESY spectrum of compound 3 (in $\mathrm{CD}_{3} \mathrm{OD}, 800 \mathrm{MHz}$ )

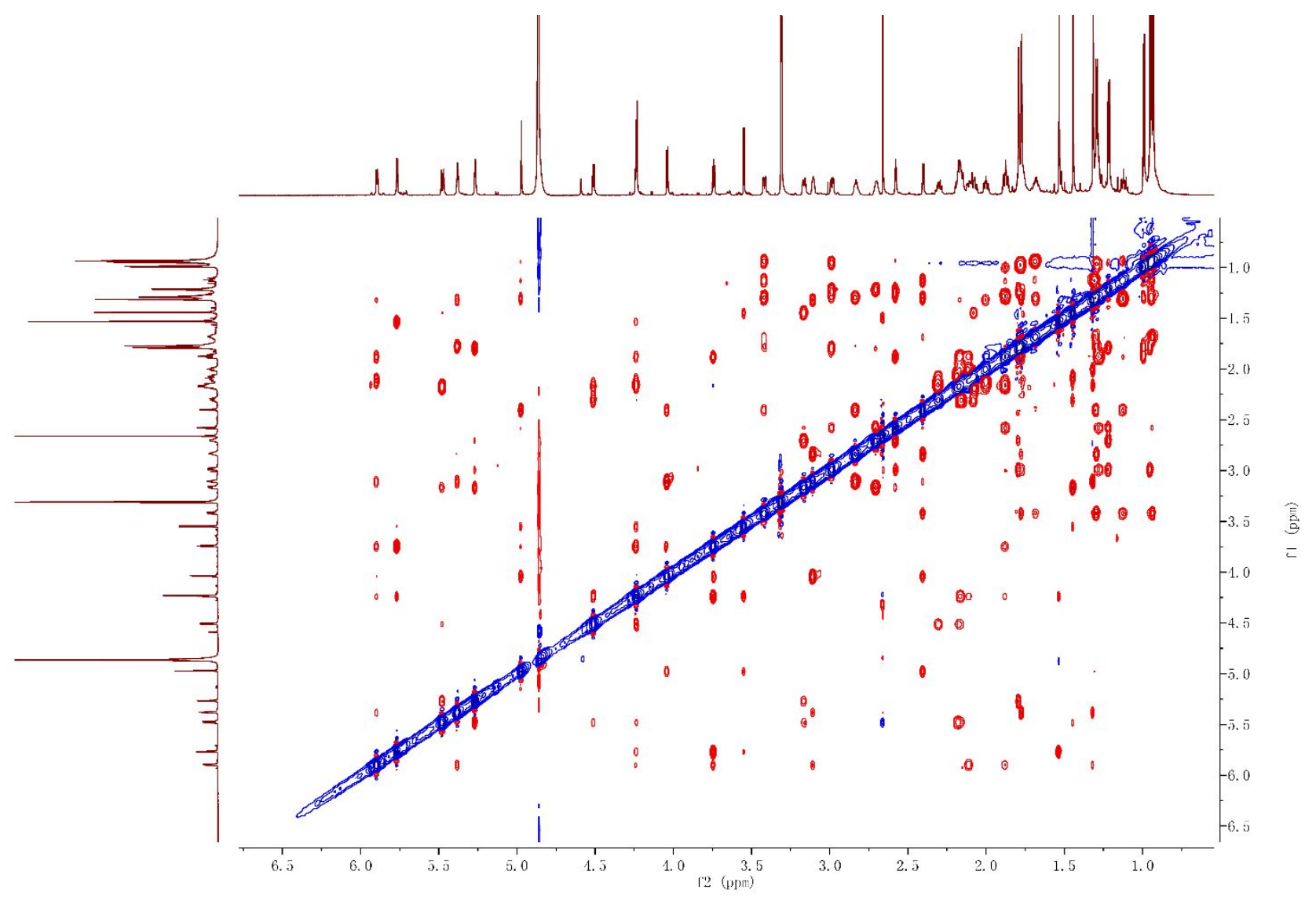

